\title{
Distributional Effects of Means Testing Social Security: An Exploratory Analysis
}

Alan Gustman, Thomas Steinmeier, and Nahid Tabatabai

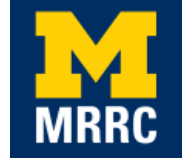

Project \#: UM14-01 



\title{
Distributional Effects of Means Testing Social Security: An Exploratory Analysis
}

\author{
Alan Gustman \\ Dartmouth College \\ Thomas Steinmeier \\ Texas Tech University \\ Nahid Tabatabai \\ Dartmouth College \\ August 2014 \\ Michigan Retirement Research Center \\ University of Michigan \\ P.O. Box 1248 \\ Ann Arbor, MI 48104 \\ www.mrrc.isr.umich.edu \\ (734) 615-0422
}

\section{Acknowledgements}

This work was supported by a grant from the Social Security Administration through the Michigan Retirement Research Center (Grant \# 2 RRC08098401-06-00), with a subcontract to Dartmouth College. The findings and conclusions expressed are solely those of the author and do not represent the views of the Social Security Administration, any agency of the Federal government, or the Michigan Retirement Research Center. 


\title{
Distributional Effects of Means Testing Social Security: An Exploratory Analysis
}

\begin{abstract}
This paper examines the distributional implications of introducing additional means testing of Social Security benefits where proceeds are used to help balance Social Security's finances. Benefits of the top quarter of households ranked according to the relevant measure of means are reduced using a modified version of the Social Security Windfall Elimination Provision (WEP). The replacement rate in the first bracket of the benefit formula, determining the Primary Insurance Amount (PIA), would be reduced from 90 percent to 40 percent of Average Indexed Monthly Earnings (AIME).

Four measures of means are considered: total wealth; an annualized measure of AIME; the wealth value of pensions; and a measure of average indexed W2 earnings. The empirical analysis, based on data from the Health and Retirement Study, starts with a baseline benefit for each household, calculated as the product of the average benefit-tax ratio under the current system, multiplied by the taxes paid by the household.

These means tests would reduce total household benefits by 7 to 9 percentage points, amounting to 15.4 to 16.4 percent of the benefits of affected workers at baseline. We find that the basis for means testing Social Security makes a substantial difference as to which households have their benefits reduced, and that different means tests may have different effects on the benefits of families in similar circumstance. We also find that the measure of means used to evaluate the effects of a means test makes a considerable difference as to how one would view the effects of the means test on the distribution of benefits.
\end{abstract}

\section{Citation}

Gustman, Alan L., Thomas L. Steinmeier, and Nahid Tabatabai (2014). "Distributional Effects of Means Testing Social Security: An Exploratory Analysis.” University of Michigan Retirement Research Center (MRRC) Working Paper, WP 2014-306. Ann Arbor, MI. http://www.mrrc.isr.umich.edu/publications/papers/pdf/wp306.pdf 


\section{Introduction}

Policymakers are again focusing on the question of how best to strengthen the finances of the Social Security system. Some are considering introducing new means tests as at least a partial solution to its long term financial imbalance. ${ }^{1}$

To provide some perspective on new approaches to means testing, we develop a menu of options involving different definitions of means. We then use data from the Health and Retirement Study (HRS) to investigate the consequences of the various possible choices for the level and redistribution of Social Security benefits fostered by each approach.

The elements of a means test include: the unit being subject to the means test (individual or household); the Social Security benefits that are being adjusted (own benefits for one or both spouses; spouse or survivor benefits); the measure of means (current earnings; lifetime covered earnings; total wealth; the value of pensions; and total income earned over the lifetime in all work, whether covered or not); once means are measured, the definition of "high means;" and the formula that is used to reduce the benefits of those unit's that are judged to have "high means.”

It seems logical that any scheme to redistribute “old age” Social Security benefits based on means should consider the total benefits paid to the household, where throughout this paper households may be composed of either one person or a married couple. In contrast, as explained below, under the current system, redistribution of benefits is determined at the level of the individual, and is modified by a "top up" for spouse and survivor benefits. Attempting to accomplish redistribution at the level of the

\footnotetext{
${ }^{1}$ For an introduction to means testing Social Security and its consequences, see American Academy of Actuaries (2012).
} 
individual weakens the relation between benefits paid to a household and the total

covered earnings of the two spouses in the household. The effect is to reduce the amount of redistribution among households with different levels of earnings. ${ }^{2}$

While the current system bases redistribution of benefits on a measure of lifetime covered earnings (Average Indexed Monthly Earnings, or AIME), current proposals would also consider other measures of means. In this paper, we consider means tests based on lifetime earnings (covered or total), total wealth, and pension wealth. ${ }^{3}$

To limit the number of possible combinations of elements for designing a means test, in this paper we restrict the form of the means test. We employ a method for reducing benefits that Social Security already uses to reduce the benefits of individuals who worked in and earned a pension from uncovered employment. To be more specific, we use a version of the Social Security Windfall Elimination Provision (WEP) to reduce benefits of households with high means. ${ }^{4}$ We also clearly delineate the population affected by the means test we analyze. In particular, we reduce the generosity coefficient

\footnotetext{
${ }^{2}$ See Gustman and Steinmeier (2001); Liebman (2002); Coronado, Fullerton and Glass (2011); Coe, Karamcheva, Kopcke, and Munnell (2011); and Gustman, Steinmeier and Tabatabai (2013). These studies show that although the Social Security benefit formula is designed to redistribute benefits toward individuals with low lifetime earnings, there is much less redistribution of benefits at the household level than at the individual level, i.e., from households with high lifetime covered earnings to households with low covered earnings.

${ }^{3}$ It has been argued that pensions are unduly favored by the tax law, and recent proposals, e.g., by Representative Camp, would apply a means test to pension benefits. Any effort to use pensions as a measure of means would, of course, have an adverse effect on saving through pension plans.

${ }^{4}$ To mitigate what Congress considered to be an unwarranted redistribution in favor of double dippers, WEP reduces the very high replacement rate up to the first bend point in the Social Security benefit formula from 90 percent to as low as 40 percent. This adjustment essentially reduces Social Security benefits of a fully affected worker by roughly $\$ 5,000$. Applied at the household level, it would lead to a reduction of annual Social Security benefits of up to $\$ 10,000$ for a household judged as having high means. (For further discussion of WEP, see Gustman, Steinmeier and Tabatabai, 2014.)
} 
of the Social Security benefit formula only for the top quarter of households, as ranked by one of the four measures of means. ${ }^{5}$

By its very definition, means testing reinforces the redistributive goal of Social Security at the expense of the system's ability to provide fair insurance. ${ }^{6}$ In addition, if means testing is meant to solve some of Social Security's financial problems, and as a consequence it reduces the pool of benefits available to all covered workers, means testing may reduce the ability of Social Security to meet either of its goals, to provide fair insurance or to support older retirees with low lifetime incomes. ${ }^{7}$

Data are readily available to the Social Security Administration to support some versions of means testing, but are not available for others. Social Security does not aggregate individuals into households until after retirement, and even then does not do so for all households. ${ }^{8}$ Nor does the Social Security Administration currently solicit data either on wealth or, with the exception of public employees who were employed in uncovered jobs, on pensions. That is not to say that these data could not be collected. For example, wealth data are collected in determining student loans, and pension data could

\footnotetext{
${ }^{5}$ We realize that by focusing on the top quarter group we will be introducing a notch. The advantage of our approach is that it highlights the relationship between the definition of means and the households affected by the means test. The next step in our research will be to introduce a gradual adjustment in the tax rate, bridging households falling on the border of the top quartile of households and reducing benefits more sharply for those with a higher level of means.

${ }^{6}$ There has always been tension between two goals of Social Security. The first is to insure that covered workers will have adequate or minimum incomes after retirement. The second goal is to redistribute benefits progressively (Myers, 1993), providing a disproportionately higher replacement rate the lower an individual's covered earnings, as well as to provide benefits to spouses or survivors. On the one hand, if Social Security is an insurance program, there should be a close relation between the expected value of benefits and the history of taxes paid by individual units. On the other hand, redistribution requires that benefits exceed taxes paid for households designated as having lower means (that is, lower covered incomes), while benefits will then necessarily fall short of taxes paid for others with greater means. Provisions supporting both goals continue to operate, which means the system does not perfectly meet either goal.

${ }^{8}$ For further discussion, see (Compson, 2011, fn. 5).
} 
be made available by the Internal Revenue Service. Other data would be more difficult to obtain. For example, it would be very difficult to measure and adjudicate a policy based on potential household earnings if husbands and wives worked full-time, a measure of means that some view as the fairest basis for redistributing benefits, one that does not penalize households based on their work.

Before proceeding with our analysis, we should say something about approaches to means testing that we do not analyze in this paper. We do not consider basing a means test on current income, although that might seem to be a natural approach, and one that has been suggested by some policymakers. A major part of the current income of those in the population who have already claimed Social Security benefits is their current earnings (See Social Security Administration, 2014). Many forms of current income are easy to measure. But reducing benefits of those with highest current earnings would fly in the face of decades of policy initiatives that were designed to encourage older persons to delay the age of retirement.

More specifically, in the face of the wave of baby boomer retirements, Congress adopted policies to reverse the adverse effects of earnings tests and other disincentives to postponing retirement. Yet any earnings test, even one applied only to high earners, is likely to encourage earlier retirement. Among a range of Social Security policies Congress has adopted, they have abolished the Social Security earnings test for those between the full retirement age and age 70; they have raised the full retirement age from 65 to 67; and they have increased to 8 percent the delayed retirement credit, the actuarial adjustment for delayed claiming of benefits. ${ }^{9}$

\footnotetext{
${ }^{9}$ Other legislation and/or court decisions encouraged delayed retirement by abolishing various forms of age discrimination. Thus together with the courts, Congress abolished mandatory retirement; required defined
} 
If one wishes to analyze the disincentives that would be created by instituting a means test based on current earnings, there is a large literature to rely on. All that is required is to modify the literature examining the effects on retirement of what previously were inadequate actuarial adjustments to the Social Security earnings test and other features of Social Security and pensions that penalized delayed claiming of benefits.

We also do not consider proposals that would tax unearned income. That would seem to be an inferior approach to basing a means test on total wealth, which we do consider. A test based on unearned income may create distortions as wealth holders choose assets with returns that are not included in the means test (e.g., implicit returns to owner occupied housing; Piggott, 2014), adjust or time asset returns, or choose assets where the return takes the form of a capital gain that can be delayed until the asset is needed or bequeathed.

Nor do we consider the potential of modifying the income tax to further means test Social Security benefits. Under current law, Social Security is subject to income tax if AGI is more than $\$ 25,000$. For married couples filing jointly, the threshold is $\$ 44,000$. Income taxes are paid on up to 85 percent of Social Security benefits. ${ }^{10}$ The vast majority of Social Security benefits of high-income individuals are already subject to the income tax. This leaves very little room for using the income tax per se as a basis for means testing Social Security benefits.

benefit pensions to adopt actuarially fair adjustments in benefits for those who delay retiring after age 65; and similarly required employers to continue to contribute to the defined contribution pension plans of those workers who were beyond the full retirement age specified by their plan. These policies have been shown to be effective in delaying retirement. See, for example, Anderson, Gustman, and Steinmeier (1999) and Gustman and Steinmeier (2009).

${ }^{10}$ For couples filing jointly with incomes exceeding $\$ 44,000$, the amount of benefits counted in income is the lesser of 85 percent of Social Security or the sum of $\$ 6,000$ plus 85 percent of income over $\$ 44,000$. For singles, it is the lesser of 85 percent of Social Security or the sum of $\$ 4,500$ plus 85 percent of income over \$34,000. Social Security Bulletin, Annual Statistical Supplement, 2012, Table 2A31. 
To be sure, there still will be adverse effects on incentives from the means tests we do consider. For example, a wealth test will affect the incentive to save; and a test based on lifetime earnings will favor those who choose to remain out of the labor force over those who commit to full-time work over their lifetime.

Section II briefly describes how Social Security benefits are determined under the current system. Section III discusses the HRS data used in our analysis, and how those data can be used to measure the various concepts of means considered here. Section IV analyzes the distributional effects of the current system. In Section V we examine means tests based on total wealth, AIME, and pension wealth. Section VI explores heterogeneity among households affected by different means tests. Section VII concludes.

\section{The Current System}

Consider briefly the basics of Social Security benefit determination. Social Security benefits are based on a person's highest 35 years of covered earnings. Covered earnings are measured by Average Indexed Monthly Earnings (AIME). Earnings are indexed up to the year the individual turns age 60. Earnings after age 60 are not indexed and are counted on a nominal basis. The basic benefit paid at full retirement age is called the Primary Insurance Amount (PIA).

Five key features of Social Security affect the distribution of benefits and taxes.

1. The benefit formula is progressive. It replaces a decreasing share of earnings as earnings increase. In 2014, the PIA replaced 90 percent of the first $\$ 9,792$ of indexed annual earnings; 32 percent of indexed earnings between $\$ 9,792$ and $\$ 59,004$, and 15 percent of indexed earnings over that amount. (To 
facilitate later analysis, we specify earnings on an annual basis, although Social Security calculations are on a monthly basis.)

2. Annual Social Security benefits also depend on when benefits are initially claimed. If the benefit is claimed before the full retirement age, it is reduced below the PIA. If claimed after the full retirement age, the annual benefit payment is increased above the PIA by the delayed retirement credit.

3. If benefits are claimed before the full retirement age, and the individual earns income beyond an earnings disregard, benefits are reduced through an earnings test. (However, benefits lost to the earnings test are replaced in the form of higher benefit payments in the future.)

4. Under dual entitlement, the total benefit paid to a spouse who is entitled both to benefits based on own covered work and to spouse benefits will be the higher of the two. Where spouse benefits (roughly half the benefit of the primary earner) are greater than benefits from own work, the spouse benefit "tops up" the benefit from own work and the recipient is called a dual beneficiary. Similarly, the total paid to a survivor is the greater of the benefit to be received as a survivor (the benefit of the primary earner) or the benefit based on the survivor's own covered work. Again the survivor benefit is paid as a "top up” over own benefits.

5. There is a cap on covered earnings. This cap determines maximum earnings subject to the Social Security payroll tax, and provides a maximum on the covered earnings in any one year that are counted in the calculation of AIME. 


\section{The Data and Measures of Means}

Our analysis focuses on what the Health and Retirement Study (HRS) calls the Early Boomer cohort. Households are included in this cohort if they have at least one member who was age 51 to 56 in 2004. It is the latest cohort available to us that has matched Social Security earnings data.

Among the advantages of HRS data: earnings histories are reported in both covered and uncovered jobs; data are collected at the household level and not just at the individual level; it is possible to estimate own, spouse and survivor benefits; information is collected on various forms of wealth, including detailed information on pensions; and the data indicate when an individual retires and claims benefits.

Employment history, coverage by Social Security and pension coverage by job, plan type, and benefits are reported in the respondent interview. During the baseline survey in 2004, respondents are asked about their current job, last job if not currently employed, most recent previous job lasting five or more years, and two additional previous jobs lasting at least five years that offered a pension. Matched administrative records provided by The Social Security Administration report covered earnings in each year of work.

For respondents who have not yet retired, we calculate own Social Security benefits from working on a covered job by applying the Social Security Administration's ANYPIA (batch calculator) program to the covered earning records for the respondent. When earnings or benefit records are not available from the Social Security Administration, we impute them based on individual and job characteristics, including self-reported earnings. 
Once the values of own benefits are calculated, the respondents are merged into households. Own, spouse, and survivor benefits are calculated at the household level and are summed to generate total household Social Security benefits. AIME, our measure of lifetime covered earnings, is also calculated at the household level. Benefits are discounted over the lifetime using expected interest rates and life tables from the Social Security Administration.

Social Security is designed to be actuarially fair, paying a roughly similar benefit over the lifetime no matter what age an individual claims benefits. ${ }^{11}$ Depending on when an individual retires, annual benefits may vary by up to 75 percent, e.g., between two individuals with identical covered earnings histories, one who claims benefits at age 62, and another with identical lifetime covered earnings who claims benefits at age $70 .{ }^{12}$

Respondents also report the balances from live defined contribution plans held on current or previous jobs. In the case of defined benefit pensions, respondents report expected or actual benefits and expected or actual ages of benefit claiming.

In evaluating Social Security and pension benefits from reports of expected benefits, we use three different key dates: zero earnings are projected for all years after the date an individual leaves the labor force; for this date we use either the actual retirement date or the date when respondents in the self-reported retirement sequence say they expect to stop working (or 62 if that was missing, or 70 if the expectation was working past 70). For the expected date of claiming Social Security benefits, we use the

\footnotetext{
${ }^{11}$ With the sharp decline the in the interest rate resulting from aggressive monetary policy aimed at inducing recovery from the Great Recession, there is a modest reward to delaying claiming after reaching the early entitlement age. (Shoven and Slavov, 2012).

${ }^{12}$ When conducting means tests based on wealth, we evaluate Social Security benefits as a stock. We do not consider a means test that is based on annual income and includes Social Security as part of annual income. A means test that is based partially on annual Social Security benefits would create a difference in lifetime benefits received, even when there is no difference in lifetime covered earnings (AIME), and thus no difference in the value of benefits that these covered workers are entitled to over their lifetimes.
} 
respondent's self-report of when (s)he expects to receive Social Security benefits; again using 62 if missing and 70 for 70 and older. In evaluating pensions, we use the date when the individual reports expecting to begin claiming those benefits. Comparisons are then made on a present value basis.

\section{Covariation Among Different Measures of Means}

We would like to know whether it makes much difference which measure of means is used as the basis for the means test. A first question, then, is how closely related the different measures of means are to one another. We focus in Table 1 on the correlations among three measures of means, household total wealth, household AIME and household pension wealth. Below we consider the fourth, household W2 earnings.

Before turning to the correlation coefficients, note that we expect them to be positive and relatively large. AIME determines Social Security benefits, and Social Security wealth is a major part of total wealth. Similarly, pension wealth is included in total wealth, and with a common component, a positive correlation is expected. But our interest is in determining whether these positive correlations are so large that it makes little difference which is chosen as the basis for a means test.

Table 1: Correlation Coefficients Among Household Total Wealth, AIME, and

\section{Pension Wealth}

\begin{tabular}{|l|l|}
\hline & Correlation Coefficients \\
\hline AIME and Total Wealth & 0.795 \\
\hline Total Wealth and Pension Wealth & 0.701 \\
\hline AIME and Pension Wealth & 0.631 \\
\hline
\end{tabular}


Household AIME and total wealth are correlated .795, which suggests a number of households will be affected differently if the means test is based on AIME than if it is based on total wealth. This imperfect correlation is consistent with Venti and Wise (1999, 2001) and Gustman and Steinmeier (1999), who found wide distributions of wealth when the population was divided into deciles according to lifetime incomes. More detail is provided in Appendix Table 1, which reports the counts of observations in each cell when wealth deciles are shown in the column heads and AIME deciles appear as row heads. Only 797 out of 2,439 observations fall along the main diagonal where they are in the same decile in both the wealth and AIME distribution. ${ }^{13}$

Total household wealth and pension wealth are correlated .701. This imperfect relationship is consistent with Gustman and Steinmeier (1999), who examined the substitution of pensions for other forms of saving and found the substitution between pension and other forms of total wealth was much less than perfect. Those with a pension exhibited higher overall wealth, income constant. But the difference in wealth between those with and without a pension was less than the value of the pension. These findings revealed considerable heterogeneity in the degree of substitution. Further detail is provided in Appendix Table 2, where total wealth and pension wealth are divided into deciles. Nine hundred and forty four of 2439 observations fall along the main diagonal.

Analogously, the relation between household AIME and pension wealth is imperfect, with a correlation of 0.631. Appendix Table 3 shows the relation when AIME and pension wealth are divided by decile.

\footnotetext{
${ }^{13}$ Including one cell to the right and left of each diagonal element, 1,633 observations are captured, which still leaves 806, or one third of the observations, falling well outside the diagonal.
} 
As would be expected, there is an imperfect correspondence among households falling within the top three deciles when ranked by total wealth, AIME, or pension wealth. Consequently, some households whose Social Security benefits are reduced under one measure of means will not have their benefits affected should another measure be used as the standard for high means. The bottom line is that we can expect means tests based on AIME, total wealth, and pension wealth to affect many families differently. This will be apparent in our later findings.

In addition to records on covered earnings, W2 records are also available. They provide information on covered and uncovered earnings dating back to 1980. Box 1 of the W2 record reports total earnings, while box 3 reports earnings covered by Social Security. Earnings from self-employment and earnings from employment not covered by Social Security (non-FICA earnings) are also reported. ${ }^{14}$ We eliminate from our samples all households with earnings from uncovered work. The W2 records are still useful, however, in that they include earnings above maximum taxable earnings subject to the payroll tax. Because the W2 earnings are available only for later years of work, they will overstate average earnings over the lifecycle. Thus the W2 earnings are not meant to be a substitute for covered earnings, but a supplement to them providing an alternative way to rank households as to their means.

\footnotetext{
${ }^{14}$ Self-employment earnings are not consistently reported over the full period. Before 1993, if a person had earnings as an employee, where the earnings were subject to the payroll tax, while also having selfemployment income, self-employment income was only reported until the sum of total earnings reached maximum covered earnings for determining Social Security payroll tax payments. Thus a person with a relatively well-paid job in covered employment who also worked in self-employment might not have the full self-employment income reported. Since employee earnings took precedence, for those with taxable earnings at the maximum, earnings from self-employment would vary inversely with the level of employee earnings. This problem was remedied in 1993 when the cap on earnings subject to the Medicare tax was abolished so that all self-employment earnings were reported.
} 
Unfortunately, the W2 data are only available for a limited sample. More specifically, the W2 data are only reliably available from 1982 through 2008 depending on the years when permission was given for a match. ${ }^{15}$ The oldest member of the Early Boomers would have been age 34 in 1982. The youngest member of the Early Boomer cohort was age 50 in 2003. Therefore, after indexing, we will average W2 earnings from ages 34 to 50 and use that average as a measure of lifetime earnings. The index we use is the measure of average wages used by the Social Security Administration to index earnings when calculating AIME. ${ }^{16}$

For out-of-age-range individuals with earnings above maximum covered earnings, the missing W2 information will be important. Consequently, we calculate average W2 earnings only for those households where both spouses were 34 to 50 in 2004, and where W2 earnings records are available for both spouses. We then compare findings using W2 data for this smaller sample with the outcomes obtained for the reduced sample when we measure means by AIME, total wealth, or pension wealth.

Correlation coefficients are reported in Table 2 for the reduced sample where the households have a matched W2 record, and W2 earnings are observable between ages 34 and 50. With 655 households in the sample, AIME is correlated with total wealth $0.857 .{ }^{17}$ Wealth is correlated with W2 earnings .812. From Appendix Table 4, we see that when

\footnotetext{
${ }^{15}$ The W2 data reported in the first years of the Earnings Records are subject to error. Viable records begin in 1982.

${ }^{16}$ Given the limited number of years of W2 data available, many households do not have W2 earnings reported for all ages from ages 34 to 50. Many spouses who fall outside the Early Boomer age range are too old to have their earnings at age 34 included in the W2 records. Analogously, much younger spouses will not have observed W2 earnings at age 50. As a partial remedy, it is possible to use AIME records for those out-of-age-range individuals whose earnings never exceed the cap.

${ }^{17}$ Within this restricted sample, when wealth and AIME are arrayed by decile, 224 of 655 observations, or 34 percent of observations, fall along the main diagonal. This 0.857 correlation between AIME and total wealth in restricted sample compares with a correlation of .795 within the full sample of 2,439, with 797, or 32.7 percent, of the observations falling along the main diagonal.
} 
W2 earnings and total wealth are arrayed by decile, 213 of 655 observations fall along the main diagonal.

Table 2: Correlation of Coefficients Between Wealth, AIME, Pension Wealth, and W2 Earnings for the Households with 16 years of W2 Earnings Data

\begin{tabular}{|l|l|l|l|}
\hline & Total Wealth & Pension Wealth & W2 Earnings \\
\hline AIME & 0.857 & 0.695 & 0.948 \\
\hline Total Wealth & & 0.750 & 0.812 \\
\hline Pension Wealth & & & 0.689 \\
\hline
\end{tabular}

Table 2 provides an important piece of encouraging news. AIME on an annualized basis appears to be quite closely related to W2 earnings, at least within the limited sample for which W2 earnings are available. The correlation is .948. In Appendix Table 5, where AIME and W2 deciles are arrayed, 338 of 655 observations fall along the main diagonal, while 592 of 655 observations fall within one cell of the diagonal. This suggests that AIME will provide a useful indicator of lifetime earnings, even though earnings are only counted up to the cap. Note, however, that we have excluded anyone who had earnings from uncovered work, which has the effect of bringing these two measures closer together.

Tables 3 through 5 illustrate the very different asset compositions within deciles when households are ranked by AIME, total wealth, and pension wealth. These tables report the values of the various components of wealth and the share of total wealth represented by those components within each specified decile. Next we would like to 
illustrate the differences in heterogeneity among households when different definitions of means are used.

Table 3 divides households according to AIME decile. The positive relation between AIME and total wealth is apparent from the values for wealth reported in row 1. As AIME increases, the average value of total wealth rises from \$83,000 in AIME decile 1 to $\$ 1,442,000$ for those households falling in the highest AIME decile.

From the first column of Table 3, 42.9 percent $(\$ 36,000)$ of the total wealth of households in the lowest AIME decile is in the form of Social Security wealth. Nineteen thousand dollars, representing 22.6 percent of their total wealth, is in the form of pensions. Housing represents another 22.6 percent of their total wealth. Altogether, Social Security, pensions, and housing represent 89 percent of the total wealth of households in the lowest AIME decile, with other forms of financial and other wealth representing only 11 percent of total wealth.

Looking over to the next to last column, those in the top AIME decile, with total wealth of $\$ 1,442,000$, had $\$ 476,000$, or 33 percent, of their total wealth in the form of Social Security. From row 3 of the next to last column, $\$ 431,000$, or 29.9 percent, of their total wealth was in the form of pensions. Housing, worth $\$ 230,000$, represented 16 percent of their total wealth. Altogether, Social Security, pensions, and housing represented 79 percent of the total wealth of households in the top AIME decile, with slightly more than one-fifth of total wealth represented by financial and other assets.

Looking across row 2, although total wealth increases with household AIME, the share of total wealth represented by Social Security begins to decline, but only once the 
sixth AIME decile is reached. Moreover, that decline is not very steep. By the highest AIME decile, one-third of total wealth is still represented by Social Security. 
Table 3: Components of Wealth for All Age Eligible* Households in the Early Boomer Cohort by AIME Deciles (All values are in thousands of dollars)

\begin{tabular}{|c|c|c|c|c|c|c|c|c|c|c|c|}
\hline Deciles & $0-10 \mathrm{~K}$ & $10-19$ & $19-30$ & 30-39 & $39-50$ & $50-62$ & $62-74$ & 74-86 & 86-103 & $103+$ & Total \\
\hline $\begin{array}{l}\text { Total } \\
\text { Wealth }\end{array}$ & 83 & 244 & 287 & 424 & 507 & 7774 & 854 & 931 & 1,187 & $1,1,442$ & 673 \\
\hline $\begin{array}{l}\text { Social } \\
\text { Security }\end{array}$ & $\begin{array}{c}36 \\
(42.9 \%)\end{array}$ & $\begin{array}{c}111 \\
(45.5 \%)\end{array}$ & $\begin{array}{c}162 \\
(56.4 \%)\end{array}$ & $\begin{array}{c}196 \\
(46.6 \%)\end{array}$ & $\begin{array}{c}262 \\
(51.7 \%)\end{array}$ & $\begin{array}{c}296 \\
(38.2 \%)\end{array}$ & $\begin{array}{c}345 \\
(40.4 \%)\end{array}$ & $\begin{array}{c}388 \\
(41.7 \%)\end{array}$ & $\begin{array}{c}410 \\
(34.5 \%)\end{array}$ & $\begin{array}{c}476 \\
(33.0 \%)\end{array}$ & $\begin{array}{c}268 \\
(39.8 \%)\end{array}$ \\
\hline Pension & $\begin{array}{c}19 \\
(22.6 \%)\end{array}$ & $\begin{array}{c}37 \\
(15.2 \%)\end{array}$ & $\begin{array}{c}34 \\
(11.8 \%)\end{array}$ & $\begin{array}{c}65 \\
(15.4 \%)\end{array}$ & $\begin{array}{c}87 \\
(17.2 \%)\end{array}$ & $\begin{array}{c}155 \\
(20.0 \%)\end{array}$ & $\begin{array}{c}213 \\
(24.9 \%)\end{array}$ & $\begin{array}{c}189 \\
(20.3 \%)\end{array}$ & $\begin{array}{c}283 \\
(23.8 \%)\end{array}$ & $\begin{array}{c}431 \\
(29.9 \%)\end{array}$ & $\begin{array}{c}151 \\
(22.4 \%)\end{array}$ \\
\hline House & $\begin{array}{c}19 \\
(22.6 \%)\end{array}$ & $\begin{array}{c}36 \\
(14.8 \%)\end{array}$ & $\begin{array}{c}44 \\
(15.3 \%)\end{array}$ & $\begin{array}{c}77 \\
(18.3 \%)\end{array}$ & $\begin{array}{c}75 \\
(14.8 \%)\end{array}$ & $\begin{array}{c}123 \\
(15.9 \%)\end{array}$ & $\begin{array}{c}130 \\
(15.2 \%)\end{array}$ & $\begin{array}{c}145 \\
(15.6 \%)\end{array}$ & $\begin{array}{c}196 \\
(16.5 \%)\end{array}$ & $\begin{array}{c}230 \\
(16.0 \%)\end{array}$ & $\begin{array}{c}107 \\
(15.9 \%)\end{array}$ \\
\hline $\begin{array}{l}\text { Other } \\
\text { Assets** }\end{array}$ & $\begin{array}{c}10 \\
(11.9 \%)\end{array}$ & $\begin{array}{c}61 \\
(24.9 \%)\end{array}$ & $\begin{array}{c}47 \\
(16.4 \%)\end{array}$ & $\begin{array}{c}84 \\
(20.0 \%)\end{array}$ & $\begin{array}{c}82 \\
(16.2 \%)\end{array}$ & $\begin{array}{c}200 \\
(25.8 \%)\end{array}$ & $\begin{array}{c}165 \\
(19.3 \%)\end{array}$ & $\begin{array}{c}209 \\
(22.4 \%)\end{array}$ & $\begin{array}{c}299 \\
(25.2 \%)\end{array}$ & $\begin{array}{c}305 \\
(21.2 \%)\end{array}$ & $\begin{array}{c}146 \\
(21.7 \%)\end{array}$ \\
\hline Obs. ${ }^{* * *}$ & 288 & 263 & 260 & 248 & 255 & 243 & 236 & 225 & 215 & 206 & 2439 \\
\hline
\end{tabular}

*Age eligible households in 2004 include all families with at least one member being 51 to 56 years of age in 2004. Households with at least one member of the household being identified as a noncovered employee are excluded.

** Other Assets include real estate, business, finance, vehicles, and IRA accounts.

***The deciles are constructed using the household weights in 2004. The number of observations in the bottom row reports the number of unweighted households falling within each weighted decile. 
Table 4: Components of Wealth for All Age Eligible* Households in the Early Boomer Cohort by Wealth Deciles (All values are in thousands of dollars)

\begin{tabular}{|c|c|c|c|c|c|c|c|c|c|c|c|}
\hline Deciles & $0-95 \mathrm{~K}$ & $95-171$ & $171-252$ & $252-355$ & $355-493$ & $493-630$ & $630-796$ & 796-1078 & $1078-1510$ & $1510+$ & Total \\
\hline $\begin{array}{l}\text { Total } \\
\text { Wealth }\end{array}$ & 41 & 131 & 209 & 305 & 4419 & 2561 & 706 & 930 & $\begin{array}{l}1,269 \\
\end{array}$ & $2,2,156$ & 673 \\
\hline $\begin{array}{l}\text { Social } \\
\text { Security }\end{array}$ & $\begin{array}{c}40 \\
(95.2 \%)\end{array}$ & $\begin{array}{c}118 \\
(90.1 \%)\end{array}$ & $\begin{array}{c}170 \\
(81.3 \%)\end{array}$ & $\begin{array}{c}223 \\
(73.1 \%)\end{array}$ & $\begin{array}{c}273 \\
(65.2 \%)\end{array}$ & $\begin{array}{c}323 \\
(57.5 \%)\end{array}$ & $\begin{array}{c}347 \\
(49.2 \%)\end{array}$ & $\begin{array}{c}383 \\
(41.1 \%)\end{array}$ & $\begin{array}{c}389 \\
(30.7 \%)\end{array}$ & $\begin{array}{c}414 \\
(19.2 \%)\end{array}$ & $\begin{array}{c}268 \\
(39.8 \%)\end{array}$ \\
\hline Pension & $\begin{array}{c}1 \\
(2.4 \%)\end{array}$ & $\begin{array}{c}5 \\
(3.8 \%)\end{array}$ & $\begin{array}{c}20 \\
(9.6 \%)\end{array}$ & $\begin{array}{c}40 \\
(13.1 \%)\end{array}$ & $\begin{array}{c}68 \\
(16.2 \%)\end{array}$ & $\begin{array}{c}105 \\
(18.7 \%)\end{array}$ & $\begin{array}{c}150 \\
(21.2 \%)\end{array}$ & $\begin{array}{c}212 \\
(22.8 \%)\end{array}$ & $\begin{array}{c}362 \\
(28.5 \%)\end{array}$ & $\begin{array}{c}551 \\
(25.6 \%)\end{array}$ & $\begin{array}{c}151 \\
(22.4 \%)\end{array}$ \\
\hline House & $\begin{array}{c}3 \\
(7.1 \%)\end{array}$ & $\begin{array}{c}6 \\
(4.6 \%)\end{array}$ & $\begin{array}{c}12 \\
(5.7 \%)\end{array}$ & $\begin{array}{c}25 \\
(8.2 \%)\end{array}$ & $\begin{array}{c}49 \\
(11.7 \%)\end{array}$ & $\begin{array}{c}80 \\
(14.2 \%)\end{array}$ & $\begin{array}{c}117 \\
(16.6 \%)\end{array}$ & $\begin{array}{c}157 \\
(16.9 \%)\end{array}$ & $\begin{array}{c}219 \\
(17.3 \%)\end{array}$ & $\begin{array}{c}405 \\
(18.8 \%)\end{array}$ & $\begin{array}{c}107 \\
(15.9 \%)\end{array}$ \\
\hline $\begin{array}{l}\text { Other } \\
\text { Assets** }\end{array}$ & $\begin{array}{c}-2 \\
(-4.8 \%)\end{array}$ & $\begin{array}{c}2 \\
(1.5 \%)\end{array}$ & $\begin{array}{c}7 \\
(3.3 \%)\end{array}$ & $\begin{array}{c}17 \\
(5.6 \%)\end{array}$ & $\begin{array}{c}29 \\
(6.9 \%)\end{array}$ & $\begin{array}{c}53 \\
(9.4 \%)\end{array}$ & $\begin{array}{c}93 \\
(13.2 \%)\end{array}$ & $\begin{array}{c}178 \\
(19.1 \%)\end{array}$ & $\begin{array}{c}299 \\
(23.6 \%)\end{array}$ & $\begin{array}{c}786 \\
(36.5 \%)\end{array}$ & $\begin{array}{c}146 \\
(21.7 \%)\end{array}$ \\
\hline Obs. ${ }^{* * *}$ & 282 & 258 & 250 & 254 & 260 & 238 & 231 & 231 & 231 & 204 & 2439 \\
\hline
\end{tabular}

*Age eligible households in 2004 include all families with at least one member being 51 to 56 years of age in 2004. Households with at least one member of the household being identified as a noncovered employee are excluded.

** Other Assets include real estate, business, finance, vehicles, and IRA accounts.

****The deciles are constructed using household weights in 2004. The number of observations in the bottom row reports the number of unweighted households falling within each weighted decile. 
Table 5: Components of Wealth for All Age Eligible* Households in the Early Boomer Cohort by Pension Wealth Deciles (All values are in thousands of dollars)

\begin{tabular}{|c|c|c|c|c|c|c|c|c|c|c|c|}
\hline Deciles & 0 & 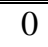 & 0 & $0-12$ & "12-38 & $38-80$ & 80-145 & $145-250$ & $250-450$ & $450+$ & Total \\
\hline $\begin{array}{l}\text { Total } \\
\text { Wealth }\end{array}$ & & & \$\$\$308 K & 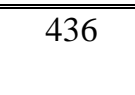 & 4889 & 629 & 751 & 819 & $\begin{array}{l}1,056 \\
\end{array}$ & $\begin{array}{l}1,646 \\
\end{array}$ & 673 \\
\hline $\begin{array}{l}\text { Social } \\
\text { Security }\end{array}$ & & & $\begin{array}{c}166 \\
(53.9 \%)\end{array}$ & $\begin{array}{c}233 \\
(53.3 \%)\end{array}$ & $\begin{array}{c}257 \\
(52.7 \%)\end{array}$ & $\begin{array}{c}312 \\
(49.7 \%)\end{array}$ & $\begin{array}{c}331 \\
(44.0 \%)\end{array}$ & $\begin{array}{c}326 \\
(39.8 \%)\end{array}$ & $\begin{array}{c}349 \\
(33.0 \%)\end{array}$ & $\begin{array}{c}383 \\
(23.3 \%)\end{array}$ & $\begin{array}{c}268 \\
(39.8 \%)\end{array}$ \\
\hline Pension & & & 0 & $\begin{array}{c}5 \\
(1.1 \%)\end{array}$ & $\begin{array}{c}23 \\
(4.7 \%)\end{array}$ & $\begin{array}{c}57 \\
(9.1 \%)\end{array}$ & $\begin{array}{c}111 \\
(14.8 \%)\end{array}$ & $\begin{array}{c}191 \\
(23.3 \%)\end{array}$ & $\begin{array}{c}336 \\
(31.8 \%)\end{array}$ & $\begin{array}{c}794 \\
(48.2 \%)\end{array}$ & $\begin{array}{c}151 \\
(22.4 \%)\end{array}$ \\
\hline House & & & $\begin{array}{c}56 \\
(18.2 \%)\end{array}$ & $\begin{array}{c}84 \\
(19.2 \%)\end{array}$ & $\begin{array}{c}80 \\
(16.4 \%)\end{array}$ & $\begin{array}{c}115 \\
(18.3 \%)\end{array}$ & $\begin{array}{c}132 \\
(17.6 \%)\end{array}$ & $\begin{array}{c}138 \\
(16.8 \%)\end{array}$ & $\begin{array}{c}159 \\
(15.1 \%)\end{array}$ & $\begin{array}{c}201 \\
(12.2 \%)\end{array}$ & $\begin{array}{c}107 \\
(15.9 \%)\end{array}$ \\
\hline $\begin{array}{l}\text { Other } \\
\text { Assets** }\end{array}$ & & & $\begin{array}{c}86 \\
(27.9 \%)\end{array}$ & $\begin{array}{c}115 \\
(26.3 \%)\end{array}$ & $\begin{array}{c}129 \\
(26.4 \%)\end{array}$ & $\begin{array}{c}144 \\
(22.9 \%)\end{array}$ & $\begin{array}{c}178 \\
(23.7 \%)\end{array}$ & $\begin{array}{c}164 \\
(20.0 \%)\end{array}$ & $\begin{array}{c}212 \\
(20.1 \%)\end{array}$ & $\begin{array}{c}268 \\
(16.3 \%)\end{array}$ & $\begin{array}{c}146 \\
(21.7 \%)\end{array}$ \\
\hline Obs. ${ }^{* * *}$ & 0 & 0 & 819 & 219 & 242 & 241 & 231 & 237 & 238 & 212 & 2439 \\
\hline
\end{tabular}

*Age eligible households in 2004 include all families with at least one member being 51 to 56 years of age in 2004. Households with at least one member of the household being identified as a noncovered employee are excluded. Households with top and bottom 1\% of wealth are excluded.

** Other Assets include real estate, business, finance, vehicles, and IRA accounts.

***The deciles are constructed using household weights in 2004. The number of observations in the bottom row reports the number of unweighted households falling within each weighted decile. 
In contrast, we see from Table 4 that when household wealth is used as the measure of means, the share of total wealth due to Social Security falls from 95.2 percent of total wealth for members of the lowest wealth decile $(\$ 40,000$, row 2 , column 1$)$ to 19.2 percent of total wealth for those in the highest wealth decile $(\$ 414,000$, row 2 , column 10). To be sure, when total wealth is used as a measure of means, the present value of Social Security benefits received by households in the top wealth decile are ten times more valuable than Social Security wealth received by those in the bottom wealth decile. But total wealth in the top decile at $\$ 2,156,000$ is 53 times as valuable as total wealth held by those in the lowest decile, at $\$ 41,000$.

If pension wealth were used to measure means as in Table 5, the bottom three deciles of pension holding households would have no pension wealth at all. Within the bottom three deciles, the present value of Social Security benefits represents 53.9 percent of total household wealth. Among the households falling within the highest decile of pension wealth, pensions represent 48.2 percent of total wealth, with Social Security accounting for 23.3 percent of total wealth.

\section{Distribution of Benefits and Taxes Under Current Law}

To understand the redistribution of Social Security benefits that would be fostered by means testing, one must first understand how the current system redistributes benefits. We begin by ordering individuals, and then households, by the annualized value of their AIME (average indexed monthly earnings).

Table 6 reports the distributions of the present values of benefits and taxes for individual respondents in the 2004 cohort of the Health and Retirement Study. Benefits reported in Table 6 include own benefits, and top ups for spouse and survivor benefits 
associated with the individual's work. That is, top ups for spouse and survivor benefits are attributed to the individual who earned them, not to the spouses who are receiving them.

In row 3, we define the present value of benefits redistributed to members of each AIME decile as the difference between (1) the benefits currently paid to members of the indicated decile, and (2) the benefits that would be paid to members of that decile if their benefits represented the same proportion of the taxes they paid over their worklife as found for the average individual in the entire sample. Note that those from the same household may fall in different AIME deciles when AIME is calculated at the level of the individual.

As seen in row 3, with the exception of the first AIME decile, members of lower deciles have their benefits increased, while members of higher AIME deciles have their benefits reduced through the redistributive effect of the formula. For example, members of the fourth AIME decile have their benefits increased by 40 percent by the current redistribution scheme. Members of the tenth AIME decile have their benefits reduced by 27 percent from what they would have been had they received the same benefit/tax ratio as the cohort as a whole, multiplied by the payroll taxes they paid.

Row 4 divides the benefits redistributed to or from the members of the indicated decile by the total amount of benefits paid to members of this cohort. Looking at the last column, row 4, altogether individuals in the top three deciles arrayed by AIME have their benefits reduced by 10.53 percent of total Social Security benefits paid to members of this cohort. The benefits lost by those in the top AIME decile are redistributed to those with lower AIME levels. 
The bottom part of Table 6 indicates the real rate of return to taxes paid. The overall distribution of returns is shown in the last column of the table. Those falling in the ninetieth percentile of returns enjoy a 4.1 percent real return on their taxes. Those with the median rate of return enjoy a 1.7 percent real rate of return. No rate of return is reported for those in the tenth rate of return percentile. Those individuals will have paid taxes but not received any benefits. For the median respondents, those in the middle row of the bottom half of the table, the real rate of return to taxes paid falls from 4.1 percent for those in the second AIME decile to 0.1 percent for those in the top AIME decile.

Table 7 does this same analysis just completed for individuals, but it does so at the level of the household. That is, the data in Table 7 reports the distribution of benefits and taxes when the lifetime covered earnings of individuals in the same household are aggregated, and the households are arrayed by AIME deciles. As can be seen from row 4, last column, when households are arrayed by AIME decile, the redistribution across deciles from high to low earning households amounts to 6.23 percent of total benefits. Compared to the baseline, under the current system households falling in the top three deciles of the AIME (lifetime covered earnings) distribution have 11.6 percent of their benefits redistributed to members of lower deciles. Households falling in the top three deciles when ranked by total wealth or pension wealth have their benefits reduced by 7.6 and 10.7 percent respectively, representing 3.7 and 5.4 percent of total Social Security benefits paid respectively. 
Table 6: Baseline Measures of Distribution and Redistribution of Own Social Security Benefits and Taxes for All Age Eligible*

\section{Individual Respondents in the Early Boomer Cohort}

\begin{tabular}{|c|c|c|c|c|c|c|c|c|c|c|c|}
\hline & \multicolumn{11}{|c|}{ Annualized Individual AIME deciles: 2004 (2004 dollars) } \\
\hline & $0-6 \mathrm{~K}$ & $6-12$ & $12-18$ & $18-24$ & $24-30$ & $30-37$ & $37-48$ & $48-60$ & $60-73$ & $73+$ & All \\
\hline Average lifetime taxes & \$14 K & 45 & 75 & 108 & 141 & 176 & 217 & 273 & 329 & 395 & 177 \\
\hline Average lifetime benefits & 7 & 63 & 94 & 121 & 137 & 159 & 183 & 200 & 212 & 230 & 140 \\
\hline $\begin{array}{l}\text { \% by which benefits are changed by } \\
\text { redistribution }\end{array}$ & $-36 \%$ & 78 & 58 & 40 & 22 & 14 & 6 & -7 & -19 & -27 & - \\
\hline $\begin{array}{l}\text { Share of total benefits redistributed to } \\
\text { the decile }\end{array}$ & $-0.29 \%$ & 1.97 & 2.47 & 2.48 & 1.76 & 1.37 & 0.77 & -1.15 & -3.54 & -5.84 & 10.53 \\
\hline \multicolumn{12}{|l|}{ Real rate of return percentiles } \\
\hline $90 \%$ & 3.9 & 5.1 & 4.4 & 4.2 & 3.6 & 3.4 & 3.2 & 2.8 & 1.9 & 1.4 & 4.1 \\
\hline $75 \%$ & - & 4.7 & 4.1 & 3.8 & 3.1 & 2.8 & 2.5 & 2.3 & 1.4 & 0.8 & 3.0 \\
\hline $50 \%$ & - & 4.1 & 3.3 & 2.9 & 2.3 & 2.1 & 1.7 & 1.6 & 0.7 & 0.1 & 1.7 \\
\hline $25 \%$ & - & 2.3 & 2.2 & 2.0 & 1.6 & 1.2 & 1.0 & 0.7 & 0.2 & -0.4 & 0.3 \\
\hline $10 \%$ & - & - & 0.8 & 0.8 & 0.9 & 0.6 & 0.3 & 0 & -0.4 & -0.8 & - \\
\hline
\end{tabular}

*Age eligible respondents in 2004 include all respondents who were between 51 to 56 years of age in 2004, or who had a 51 to 56 year old spouse in 2004 . Households with at least one member identified as working in a job that is not covered by Social Security are excluded. Respondents from households with top and bottom $1 \%$ of wealth are excluded.

** Benefits include own, spouse and survivor benefits associated with an individual's work. Spouse and survivor benefits are attributed to the individual who earned them, not to the spouses who receive them.

*** The amount of benefits redistributed to members of each AIME decile is defined as the difference between (1) benefits currently paid to members of the indicated decile, and (2) benefits that would be paid if their benefits represented the same proportion of the taxes they paid over their worklife as found for the average individual (or household) in the sample. 
Table 7: Measures of Distribution and Redistribution of Own Social Security Benefits and Taxes for All Age Eligible* Households in the Early Boomer Cohort

\begin{tabular}{|c|c|c|c|c|c|c|c|c|c|c|c|}
\hline & \multicolumn{11}{|c|}{ Annualized Households AIME deciles: 2004 (2004 dollars) } \\
\hline & $0-10 \mathrm{~K}$ & $10-19$ & $19-30$ & $30-39$ & $39-50$ & $50-62$ & $62-74$ & $74-86$ & 86-103 & $103+$ & All \\
\hline Average lifetime taxes & $\$ 26 \mathrm{~K}$ & 77 & 126 & 179 & 228 & 286 & 338 & 402 & 459 & 604 & 272 \\
\hline Average lifetime benefits & 34 & 111 & 162 & 196 & 262 & 296 & 345 & 388 & 410 & 476 & 268 \\
\hline $\begin{array}{l}\text { \% by which benefits are changed by } \\
\text { redistribution }\end{array}$ & $39 \%$ & 46 & 30 & 11 & 17 & 5 & 4 & -2 & -9 & -20 & - \\
\hline $\begin{array}{l}\text { Share of total benefits redistributed to } \\
\text { the decile }\end{array}$ & $0.38 \%$ & 1.30 & 1.40 & 0.72 & 1.44 & 0.54 & 0.45 & -0.30 & -1.56 & -4.37 & 6.23 \\
\hline \multicolumn{12}{|l|}{ Real rate of return percentiles } \\
\hline $90 \%$ & 4.7 & 4.5 & 4.0 & 3.6 & 3.4 & 3.0 & 2.9 & 2.6 & 2.2 & 1.7 & 3.7 \\
\hline $75 \%$ & 3.9 & 4.1 & 3.5 & 2.9 & 2.9 & 2.4 & 2.3 & 1.9 & 1.8 & 1.3 & 2.7 \\
\hline $50 \%$ & - & 3.3 & 2.8 & 2.3 & 2.1 & 1.7 & 1.5 & 1.2 & 1.0 & 0.6 & 1.7 \\
\hline $25 \%$ & - & 1.8 & 1.8 & 1.0 & 1.3 & 0.9 & 0.6 & 0.5 & 0.1 & 0.1 & 0.5 \\
\hline $10 \%$ & - & 0.9 & 1.11 & 0.5 & 0.6 & 0.1 & 0 & -0.2 & -0.3 & -0.5 & -0.4 \\
\hline
\end{tabular}

*Age eligible respondents in 2004 include all families with at least one member being between 51 to 56 years of age in 2004. Households with at least one member being identified as a noncovered employee are excluded. Households with top and bottom $1 \%$ of wealth are excluded.

** We define the amount of benefits redistributed to members of each AIME decile as the difference between (1) the benefits currently paid to members of the indicated decile, and (2) the benefits that would be paid to members of that decile if their benefits represented the same proportion of the taxes they paid over their worklife as found for the average individual (or household) in the sample. 
Again for those at the 50th percentile one sees a decline in the real rate of return as AIME increases. The real rate of return declines from 3.3 percent for households in the second AIME decile to 0.6 percent for those in the top AIME decile. Thus the fall in the real rate of return for the median household involves a decline of 2.7 percentage points from the second to tenth decile, while for the median individual it fell by 4 percentage points over a similar range. Clearly although there is a progressive benefit formula at the individual level, it is less successful in redistributing benefits among households than among individuals. ${ }^{18}$

It is most meaningful to conduct the analysis of benefit redistribution at the level of the household rather than at the level of the individual. At the individual level, benefits are redistributed toward low-earning spouses from households where the primary earner has high-covered earnings. Conducting the analysis at the household level is also useful because wealth, one of the criteria we will use to categorize household means, is measured at the household level and is difficult to attribute to each spouse in married households.

Table 8 summarizes the redistribution among households fostered by the current system under three different definitions of means: annualized AIME, representing lifetime covered earnings; total wealth; and pension wealth.

If lifetime covered earnings is the relevant criterion, then the current system redistributes 6.23 percent of total discounted Social Security benefits from households

\footnotetext{
${ }^{18}$ In 1992, for respondents age 51 to $61,10.6$ percent of discounted benefits were redistributed among individuals, while 5.0 percent of benefits were redistributed among households (Gustman and Steinmeier, 2001). As noted above, for those ages 51 to 56 in 2004, 10.5 percent of benefits are redistributed at the individual level, while 6.2 percent of benefits are redistributed at the household level. In addition to the age differences between the samples, two other differences between the samples underlying these results should be noted. In the present paper, members of households falling within the top 1 percent of wealth holding households have been eliminated from the sample. In addition, households where at least one respondent has worked in a job not covered by Social Security have been eliminated.
} 
with high AIME (falling in the top three deciles) to households with low AIME. When households are ranked by total wealth, the current system redistributes 3.66 percent of total Social Security benefits from those falling in the highest wealth deciles to those falling in the lower wealth deciles. If pension wealth is the relevant criterion, the current system redistributes 5.36 percent of total Social Security benefits from those falling in the highest pension wealth deciles to those falling in the lowest deciles.

Table 8: The Difference in the Share of Benefits Redistributed to Lower Deciles of Households by the Current System, by Basis for the Means Test

\begin{tabular}{|c|c|c|}
\hline \multicolumn{3}{|c|}{ Redistribution Among } \\
\hline \hline AIME Deciles & Total Wealth Deciles & Pension Wealth Deciles \\
\hline 6.23 & 3.66 & 5.36 \\
\hline
\end{tabular}

\section{Means Tests Based on AIME, Total Wealth, and Pension Wealth}

The means test we use reduces the generosity coefficient up to the first bend point of the PIA formula from .9 to .4 for those falling in the top quarter of households ranked by whatever measure of means is being used. This approach allows us to greatly simplify our analysis by imposing the same penalty on a given household whether it is declared to fall in the top quarter of households because of its AIME, because of its total wealth, or because of pension wealth. As we will see, some households will be subject to the means test under one criterion but not others, some under two criteria, and some under three criteria. Given our specification of the means test, we will not have to further complicate 
the analysis by allowing the penalty for a given household to vary depending on the criteria used to determine who is subject to the means test.

If the household is in the upper 25 percent by whatever measure, the reduction of the first bracket from 90 percent to 40 percent applies to the PIA calculations for both spouses. Spouse and survivor benefits are similarly adjusted. Because households include both single individuals and couples, and households in the top 25 percent include a disproportionate share of couples, couple households will be disproportionately subject to a means test that targets the top quarter of households. Moreover, the result of any means test at the household level will be affected not only by the number of one-person vs. twoperson households, but also by the relative number of one-earner vs. two-earner households. Within two-earner households, it will further depend on whether or not the lowearner in a two-earner household is receiving only a spouse benefit, in which case the benefit reduction for the household will be $\$ 5,000+\$ 2,500$ dollars, or both spouses have earnings above the first AIME bend point, in which case the benefit reduction will be $\$ 5,000+\$ 5,000$. In later work, it will be of interest to analyze the effects of separate means tests for one- and two-person households. Below we note that our findings are similar when we restrict the analysis to couple households.

We now consider the reduction in the present value of benefits for those falling in the top three deciles relative to what they would have received in baseline. In the baseline, each household's benefit is equal to the taxes they paid multiplied by the ratio of benefits to taxes for all households in the cohort. We subtract that figure from the benefit that is paid after the means test is introduced. We then express the benefit reduction relative to total benefits that are paid to members of the cohort in baseline. 
That is, benefit reductions as a share of total benefits paid are computed as:

1. $S i=\left(\sum_{i=1}^{n} B i-\sum_{i=1}^{n} T i * \sum_{j=1}^{N} B j / \sum_{j=1}^{N} T j\right) / \sum_{j=1}^{N} B j$

Where

$\mathrm{Si}=$ the share of total benefits paid to all members of the cohort that is taken from members of the top three deciles

$\mathrm{i}=$ indicator for the $\mathrm{n}$ households in a decile

$\mathrm{j}=$ indicator for the $\mathrm{N}$ households in the complete cohort

$\mathrm{B}=$ Benefits

$\mathrm{T}=$ Taxes

The benefit reductions are the result of two factors: the redistribution away from families under the current system as a result of the progressive benefit formula; and the particular means test that is applied.

To put these means tests into perspective, when a means test based on AIME is imposed, average present values of benefits fall from 268 thousand to 245 thousand, an 8.6 percent decrease in total benefits paid. Roughly this amounts to more than one-third of the benefit decline that would be required to keep the Social Security system solvent given the current tax structure.

Tables 9 and 10 report the effects of alternative means tests. The percentage decline in benefits reported in Table 9 is the sum of redistribution under the current system from the baseline benefit plus the effect of the indicated means test. Table 10 nets out the redistribution under the current system and reports the additional redistribution from the indicated means test.

In the row heads of Table 9, we list the alternative types of means that are used in the means tests. In the column heads we list the criteria for measuring the change in benefits for members of the top three deciles. Thus, for example, if a policymaker 
thought that wealth was the appropriate way to judge means, then looking down column 2, this policymaker could judge the effects of adopting means tests based on AIME, wealth or pensions using a consistent criterion based on total wealth. Along the diagonal of Table 9, the basis of the means test and the criteria for ordering households and judging the reduction in benefits of those in the top three deciles of households coincide. The largest total reduction in benefits, relative to the baseline, occurs as a result of implementing a means test when means are defined as AIME and the means test is based on AIME. As seen in row 1, column 1, those in the top three deciles of households ranked by AIME have their benefits reduced from baseline by an amount equal to 14.84 percent of total benefits paid to members of the cohort. This reduction is due to the combined effects of redistribution under the current system plus the reduction in the Social Security benefits of those falling in the top three deciles when ranked by AIME. From row 2, column 2, when the means test and the criteria for measuring redistribution are both based on total wealth, the decline in Social Security benefits for the top three deciles of households ranked by total wealth amounts to 11.01 percent of total benefits. When pensions are the basis for defining means and the means test is based on pension wealth, the present value of Social Security benefits of those falling in the top quarter of households ranked by pension wealth are reduced by 12.59 percent of total benefits.

Remember, however, that these numbers refer to the present value of benefits taken from different sets of households, those with the highest AIME, the highest total wealth, and the highest pension wealth.

When the evaluation is based on AIME, but the means test is based on wealth, as in row 2, column 1, the top 30 percent of households judged by AIME have their benefits 
reduced by a smaller amount (11.93\% of total benefits paid to the cohort) than if the means test is based on AIME and the criterion is AIME (row 1, column 1) when benefits are reduced by $14.84 \%$. For those policymakers who think that means testing should be based on lifetime covered earnings, basing the means test on wealth or pension wealth creates a means test that is less target efficient.

Looking down column 2 where the means test is evaluated based on total wealth, more benefits will be taken from the top 30 percent of wealth holding households when the means test is based on AIME (11.52 percent of total benefits paid to the cohort) than when it is based on total wealth (11.01 percent). When the means test is evaluated based on pension wealth (column 3), there is little difference in the benefits lost by members of the top three deciles no matter what measure of means is used to implement the means test.

Looking across the rows, one can ask how a particular means test will be evaluated when it is judged based on alternative criteria. For example, looking across row 1, the combined effects of redistribution under the current system plus a means test based on AIME is judged to reduce benefits of the top 30 percent of households when ordered based on AIME (14.84\%) by more than when households are ordered based on total wealth (11.52\%) or pension wealth (12.51\%).

To report the effects of means testing alone, the numbers reported in Table 10 subtract the effects of redistribution under the current system from the total effect of redistribution and the means test combined, as reported in Table 9. Once again, the funds raised by the means test alone are used to pay off the Social Security deficit, rather than to raise the benefits of those lower down in the means distribution. 
From Table 10, we see that if one feels that AIME is the proper basis for a means test, designing the means test based on AIME will raise about three percentage points more revenue from those in the top three deciles (8.61\%) than will tests based on total wealth $(5.70 \%)$ or pension wealth (5.40\%). If one believes that total wealth or pension wealth is the appropriate basis for a means test, then whatever basis is chosen for the means test, the reduction in benefits from those in the top three deciles will be similar. 
Table 9: Percent Reduction in Benefits from Baseline by Basis for Means Test and the Measure of Means Used to Evaluate the Impact

\begin{tabular}{|l|c|c|c|}
\hline \multirow{2}{*}{$\begin{array}{l}\text { Basis for Social Security Means } \\
\text { Test }\end{array}$} & \multicolumn{3}{|c|}{ Measure of Means Used to Evaluate Impact } \\
\cline { 2 - 4 } & AIME Deciles & Wealth Deciles & $\begin{array}{c}\text { Pension Wealth } \\
\text { Deciles }\end{array}$ \\
\hline \hline $\begin{array}{l}\text { Adjusted by Top Quarter of } \\
\text { AIME }\end{array}$ & 14.84 & 11.52 & 12.51 \\
\hline $\begin{array}{l}\text { Adjusted by Top Quarter of } \\
\text { Wealth }\end{array}$ & 11.93 & 11.01 & 11.38 \\
\hline $\begin{array}{l}\text { Adjusted by Top Quarter of } \\
\text { Pension Wealth }\end{array}$ & 11.63 & 10.49 & 12.59 \\
\hline
\end{tabular}

*Baseline of benefits is defined as the product of the ratio of benefits to taxes for the entire cohort multiplied by taxes paid by the household.

Table 10: Share of Total Benefits Produced by Means Test Used to Reduced Social Security Deficit

\begin{tabular}{|l|c|c|c|}
\hline \multirow{2}{*}{$\begin{array}{l}\text { Basis for Social Security Means } \\
\text { Test }\end{array}$} & \multicolumn{2}{|c|}{ Measure of Means Used to Evaluate Impact } \\
\cline { 2 - 4 } & AIME Deciles & Wealth Deciles & $\begin{array}{c}\text { Pension Wealth } \\
\text { Deciles }\end{array}$ \\
\hline \hline Adjusted by Top Quarter of \\
AIME & $\begin{array}{c}8.61(14.84- \\
6.23)\end{array}$ & $\begin{array}{c}7.86(11.52- \\
3.66)\end{array}$ & $\begin{array}{c}7.15(12.51- \\
5.36)\end{array}$ \\
\hline $\begin{array}{l}\text { Adjusted by Top Quarter of } \\
\text { Wealth }\end{array}$ & $\begin{array}{c}5.70(11.93- \\
6.23)\end{array}$ & $\begin{array}{c}7.35(11.01- \\
3.66)\end{array}$ & $\begin{array}{c}6.02(11.38- \\
5.36)\end{array}$ \\
\hline $\begin{array}{l}\text { Adjusted by Top Quarter of } \\
\text { Pension Wealth }\end{array}$ & $\begin{array}{c}5.40(11.63- \\
6.23)\end{array}$ & $\begin{array}{c}6.83(10.49- \\
3.66)\end{array}$ & $\begin{array}{c}7.23(12.59- \\
5.36)\end{array}$ \\
\hline
\end{tabular}


Further insight into the interactions between redistribution and type of means test can be found in Appendix Tables 6, 7, and 8. In those tables the effects of means tests are reported by decile for households ranked by AIME, total wealth, and pension wealth. We also report the reduction in benefits compared to the baseline experienced by members of each decile group. For example, households falling within the highest decile ranked by AIME have their benefits reduced by 20 percent due to redistribution under the current system. With the addition of the means test, the benefits received by those in the top AIME decile would be reduced by 35 percent, or an additional 15 percent.

There are two issues related to robustness of the findings. While we have investigated the effects of basing the means test on AIME, total wealth, and pensions wealth, we also would like to know whether the results are very different when a means test is based on average, indexed, W2 earnings. Only 655 households are available for this analysis. ${ }^{19}$ To save space, we do not go through a full range of comparisons, by type of means test, by basis for measuring redistribution, by sample. We simply note that when households are ranked by W2 earnings, in the baseline, 5.90 percent of benefits are redistributed. Adding a means test based on W2 earnings would reduce the benefits of those in the top three W2 earnings deciles by an amount equal to 14.51 percent of total benefits paid in baseline. See Appendix Table 9 for additional results based on W2 earnings.

\footnotetext{
${ }^{19}$ Reliable W2 data are only available for respondents with matched records beginning in 1982, with W2 observation available to us at the latest in 2007. As a result of the availability of W2 earnings over the limited time span, members of each of these households who were ages 51 to 56 in 2004 have W2 earnings reported only from ages 34 through 50 . This rules out households with an older or younger spouse.
} 
Security benefits among couple households is more difficult to analyze than is redistribution among single person households. Thus it is useful to know that findings are similar when they are restricted to couple households to those we found using the full sample. It is also useful to know that the correspondence in results between single and couple households is not because the couple households totally dominate the sample. Out of a total sample of 2,439 households, 1,472 of the households are married couples, while 967 are single member households.

\section{Differences Among Households Affected by Different Means Tests}

In Table 11, we distinguish households according to which of the means tests, and how many of the means tests, affect them. In our sample from the Early Boomer cohort, 437 households would be affected by only one means test, 287 by two means tests, and 273 by three means tests.

The way we have structured the means test, the benefit reduction facing a particular family is independent of the criteria used to rank families. Once they fall in the top quarter based on lifetime income, wealth, or pension wealth, they are subject to the same penalty. But households that are judged to have high means based on the same criterion will be subject to different reductions in their Social Security benefits depending on the earnings history of the husband and wife. For example, when two households have the same level of wealth, they may nevertheless be subject to different reductions in their Social Security benefits.

We also see from Table 11 that households that are judged to have high means based on different criteria are often very dissimilar. Among those affected by only one means test, from column 2, row 2, those affected by a means test based on AIME have 
the highest benefits under current law with Social Security wealth of $\$ 396,000$. They would lose $\$ 87,000$ to the means test, or 22 percent of their current benefits. Those affected by only a means test based on total wealth are entitled to $\$ 315,000$ in benefits (column 2, row 3). They would lose $\$ 65,000$ in benefits, or 21 percent of their current benefits. Those subject to a means test based on pensions but not on other criteria (column 2, row 4) have $\$ 223,000$ in current benefits. They would lose 28 percent of their total benefits.

Moving down the rows, consider households affected by two means tests. Again there are wide differences among the benefits of the households affected by the different types of means tests. Those affected by a means test based AIME and a means test based on total wealth (column 2, row 6) have the highest benefits, averaging $\$ 453,000$ in Social Security wealth. They would lose 15 percent of their benefits to a means test. Those who would be subject to means tests based on AIME and pensions have lower Social Security benefits, $\$ 372,000$, but would lose 28 percent of their benefits to means tests. Those who would have their benefits reduced by means tests based on wealth and pension value, but not AIME, have the lowest Social Security wealth at $\$ 289,000$. Their benefits would be reduced by 21 percent.

The households that would be subject to a means test whether the criteria was AIME, total wealth, or pension wealth, have Social Security wealth averaging $\$ 448,000$. A means test would reduce the present value of their Social Security benefits by 18 percent.

The importance of selecting the appropriate basis for a means test can be seen by scanning down the last three columns of Table 11. For example, consider column 6. If 
one believes that wealth is the appropriate criterion for a means test, households in rows 2, 6, 8, and 9 would be subject to a means test. But if AIME were chosen as the basis for the test, the included households from rows 2 and 7 would have much lower wealth (\$609,000 and \$721,000) than households that would be selected based on a total wealth criterion (e.g., column 6, rows 3, 6, 8, and 10). 
Table 11: Number of Households and Their Benefits and Taxes by Three Means Tests Criteria

\begin{tabular}{|c|c|c|c|c|c|c|c|}
\hline & $\begin{array}{l}\text { Number of } \\
\text { households }\end{array}$ & $\begin{array}{c}\text { Benefits under } \\
\text { current law } \\
\text { in } \$ 1000\end{array}$ & $\begin{array}{l}\text { Benefits after } \\
\text { means test in } \\
\$ 1000\end{array}$ & $\begin{array}{c}\text { Ratio of } \\
\text { benefits after } \\
\text { means } \\
\text { test/benefits } \\
\text { before }\end{array}$ & $\begin{array}{l}\text { AIME in } \\
\$ 1000\end{array}$ & $\begin{array}{l}\text { Wealth in } \\
\$ 1000\end{array}$ & $\begin{array}{l}\text { Pension } \\
\text { Wealth in } \\
\$ 1000\end{array}$ \\
\hline $\begin{array}{l}\text { Only one } \\
\text { adjustment }\end{array}$ & 437 & & & & & & \\
\hline AIME only & 174 & 396 & 309 & 0.78 & 91 & 609 & 69 \\
\hline Wealth only & 107 & 315 & 250 & 0.79 & 51 & 1,509 & 44 \\
\hline $\begin{array}{l}\text { Pension } \\
\text { Wealth only }\end{array}$ & 156 & 223 & 161 & 0.72 & 47 & 593 & 285 \\
\hline Two adjustments & 287 & & & & & & \\
\hline AIME and Wealth & 106 & 453 & 383 & 0.85 & 103 & 1,479 & 80 \\
\hline AIME \& Pension & 57 & 372 & 269 & 0.72 & 92 & 721 & 272 \\
\hline Wealth \& Pension & 124 & 289 & 229 & 0.79 & 56 & 1,353 & 588 \\
\hline $\begin{array}{l}\text { Three } \\
\text { adjustments }\end{array}$ & 273 & & & & & & \\
\hline $\begin{array}{l}\text { AIME, Wealth \& } \\
\text { Pension }\end{array}$ & 273 & 448 & 369 & 0.82 & 110 & 1,577 & 564 \\
\hline
\end{tabular}

The sample size is 997. It includes only households whose benefits are adjusted by one, two, or/and three means tests criteria. 


\section{Conclusions}

Deciding on a basis for means testing would be easy if households with high lifetime covered earnings also had high total wealth and high pension wealth. But as we have seen, that is not the case for many households. As a result, different households are affected as the basis for the means test is changed. It will make a great deal of difference, at least to some households, which definition of means is chosen.

Which measure of means is chosen will also make a great deal of difference to policy makers holding specific views as to how best to define means. ${ }^{20}$ We have shown, for example, that if a policy maker believes that wealth is the appropriate basis for a means test, but another basis for means testing is in fact selected, households that are held by the policy maker to have low means will nevertheless suffer a reduction of benefits. At the heart of the problem are the imperfect correlations among total wealth, covered earnings and pension wealth.

There also is some question about internal consistency of the effects of means test even when a single criterion is used. Households falling in the top quarter when ranked by a particular criteria, whether it is lifetime covered earnings, wealth or pension wealth, will not have their benefits reduced by the same amount. Within a top quarter group, the decrease in the present value of benefits is going to depend on the covered earnings of each spouse, that is, on the mix between own and spouse or survivor benefits within the household. It is not clear that the differences in realized penalties will accord with the sense of a proper basis for means testing among those who advocate expanding means tests.

Our hope is that policy makers will be aware of the differences that alternative approaches to means testing may make, giving them a better understanding of the strengths and

\footnotetext{
${ }^{20}$ See Samwick (2012) and Samwick and Zhou (2014) for related discussions in the context of means testing health benefits and financial aid for college education.
} 
Our hope is that policymakers will be aware of the differences that alternative approaches to means testing may make, giving them a better understanding of the strengths and weaknesses of alternative definitions of means. The ultimate choice of policy, as always, depends on the preferences of the policymaker. But it is important that the complexities associated with the different choices are fully understood.

Implementing these means tests would require the Social Security Administration to collect more data than is currently available. Husbands and wives are linked in Social Security data only when they reach retirement age, and the linkages are maintained only when spouse or survivor benefits are paid. The extensive measures in the analysis, and in particular measures of wealth including pensions, would be administratively costly and require extensive data new collection on applicants. The SSI program requires this type of information of applicants and processing costs are much higher. Nevertheless, for reasons we have discussed, there are good reasons for basing means test at the household rather than at the individual level. Moreover, basing means tests on the covered earnings uses much too restrictive a measure of means. Clearly then, if what many policymakers consider to be a fair means test is to be implemented, one cost will be a very expensive and burdensome collection of new data by SSA. That cost should clearly be recognized.

In concluding, it is worth repeating a caveat with regard to disincentives created by each approach. This paper does not consider the incentive effects of means tests. As we noted at the outset, using current income as a basis for redistribution would discourage the population from delaying retirement even though that has been the goal of policies adopted in recent decades. Basing a means test on potential income assuming a full-time commitment to the labor market is the most difficult to implement on practical 
and legal grounds. The other approaches examined here all create disincentives of one type or another - reducing incentive to work, save, choose a pension, or affecting particular choice of assets to hold. These disincentives will play a major role in shaping the benefits and costs of any proposal to means test Social Security. 


\section{References}

American Academy of Actuaries. 2012. “Means Testing for Social Security: Issue Brief”.

Anderson, Patricia, Alan L. Gustman and Thomas L. Steinmeier. 1999. "Trends in Male Labor Force Participation and Retirement: Some Evidence on the Role of Pensions and Social Security in the 1970s and 1980s". Journal of Labor Economics 17(4), pt. 1: 757-783.

Coe, Norma B., Zhenya Karamcheva, Richard W. Kopcke and Alicia Munnell. 2011. "How Does the Personal Income Tax Affect the Progressivity of OASI Benefits?" Paper presented at the meeting of the Retirement Research Consortium, Washington, D.C.

Compson, Michael C. 2011. “The 2006 Earnings Public Use Micro Data File”. Social Security Bulletin 71(4).

Coronado, Julia Lynn, Don Fullerton and Thomas Glass. 2011. “The Progressivity of Social Security”. The B.E. Journal of Economic Analysis \& Policy, Berkeley Electronic Press, vol. 11(1).

Gustman, Alan L. and Thomas L. Steinmeier. 1985. "The 1983 Social Security Reforms and Labor Supply Adjustments of Older Individuals in the Long Run". Journal of Labor Economics 3(2): 237-253. . 1999. "Effects of Pensions on Savings: Analysis with Data from the Health and Retirement Study." Carnegie-Rochester Conference Series on Public Policy, 50: 271-324. 
. 2001. "How Effective Is Redistribution Under The Social

Security Benefit Formula?” Journal of Public Economics 82 (1): 1-28.

. 2004. “What People Don’t Know about Their Pensions and

Social Security: An Analysis Using Linked Data from the Health and Retirement Study.”

In William G. Gale, John B. Shoven, and Mark J. Warshawsky, eds., Private Pensions

and Public Policies. Washington, DC: Brookings Institution Press, 57-119.

.2005. "Imperfect Knowledge of Social Security and Pensions.”

Industrial Relations, 44(2): 373 -395.

2009. "How Changes in Social Security Affect Recent

Retirement Trends," with Thomas Steinmeier. Research on Aging 31(2): 261-290.

Gustman, Alan L., Thomas L. Steinmeier, and Nahid Tabatabai. 2008. “Do

Workers Know about Their Pensions? Comparing Workers’ and Employers’ Pension

Information.” In Anna Lusardi, ed., Overcoming the Saving Slump; How to Increase the

Effectiveness of Financial Education and Saving Programs. Chicago: University of

Chicago Press, 47-81.

. 2013. "Redistribution Under the Social Security Benefit

Formula at the Individual and Household Levels, 1992 and 2004". Journal of Pension

Economics and Finance 12(1): 1-27.

. 2014. "The Social Security Windfall Elimination and

Government Pension Offset Provisions for Public Employees in the Health and

Retirement Study”. Social Security Bulletin 74(3): 55-69. 
Liebman, Jeffrey B. 2002. "Redistribution in the Current U.S. Social Security System”. In Martin Feldstein and Jeffrey B. Liebman, editors. The Distributional Aspects of Social Security and Social Security Reform. Chicago: University of Chicago Press: 11 -48 .

Myers, Robert. J., 1993. Social Security, 4th Edition. Pension Research Council, Wharton School, University of Pennsylvania, and University of Pennsylvania Press, Philadelphia.

Piggott, John. 2014. "Means Testing in the Australian System of Retirement Incomes”. Michigan Retirement Research Center. Research Policy Brief (UM14-10). Samwick, Andrew A. 2012. "Means Testing Federal Health Entitlement Benefits”. Hanover, N.H.

Samwick, Andrew A. and William L. Zhou. 2014. “The Insurance Value of Financial Aid”. Hanover, N.H.

Senate Committee on Aging. 2010. “Social Security Modernization: Options to Address Solvency and Benefit Adequacy”. Report of the Special Committee on Aging, United States Senate.

Shoven, John B and Sita Nataraj Slavov. 2012a."The Decision to Delay Social Security Benefits: Theory and Evidence". NBER Working Paper No. 17866.

Social Security Administration. 2012. Social Security Bulletin, Annual Statistical Supplement. 2014. Income of the Population 55 and Older, 2012. 
Venti, Steven F., And David A. Wise. 1999. "Lifetime Earnings, Saving Choices, and Wealth at Retirement.” In James P. Smith and Robert J. Willis, Editors, Wealth, Work and Health: Innovations in Measurement in the Social Sciences. Ann Arbor, University of Michigan Press, pp. 87-120. . 2001. "Choice, Chance and Wealth Dispersion at Retirement". In Aging Issues in the United States and Japan. David A. Wise, Editor. 
Appendix: Descriptive Data 
Appendix Table 1: The Distribution of Total Wealth Deciles by AIME Deciles for Early Boomer HRS Households

\begin{tabular}{|c|c|c|c|c|c|c|c|c|c|c|c|}
\hline Deciles & $\begin{array}{c}\text { Wealth } \\
\text { Decile } 1\end{array}$ & $\begin{array}{l}\text { Wealth } \\
\text { Decile } 2\end{array}$ & $\begin{array}{l}\text { Wealth } \\
\text { Decile } 3\end{array}$ & $\begin{array}{l}\text { Wealth } \\
\text { Decile } 4\end{array}$ & $\begin{array}{l}\text { Wealth } \\
\text { Decile } 5\end{array}$ & $\begin{array}{l}\text { Wealth } \\
\text { Decile } 6\end{array}$ & $\begin{array}{l}\text { Wealth } \\
\text { Decile } 7\end{array}$ & $\begin{array}{l}\text { Wealth } \\
\text { Decile } 8\end{array}$ & $\begin{array}{l}\text { Wealth } \\
\text { Decile } 9\end{array}$ & $\begin{array}{l}\text { Wealth } \\
\text { Decile } \\
10\end{array}$ & Total \\
\hline $\begin{array}{l}\text { AIME } \\
\text { Decile } 1\end{array}$ & 222 & 28 & 15 & $\overline{77}$ & 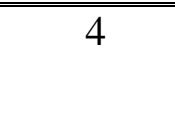 & $\bar{~} 4$ & $\bar{~} 5$ & $\bar{~} 1$ & $\overline{2}$ & 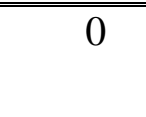 & 288 \\
\hline $\begin{array}{l}\text { AIME } \\
\text { Decile } 2\end{array}$ & 47 & 120 & 47 & 15 & 12 & 5 & 5 & 8 & 2 & 2 & 263 \\
\hline $\begin{array}{l}\text { AIME } \\
\text { Decile } 3\end{array}$ & 10 & 78 & 77 & 46 & 22 & 10 & 4 & 8 & 3 & 2 & 260 \\
\hline $\begin{array}{l}\text { AIME } \\
\text { Decile } 4\end{array}$ & 1 & 26 & 72 & 56 & 34 & 14 & 18 & 10 & 11 & 6 & 248 \\
\hline $\begin{array}{l}\text { AIME } \\
\text { Decile } 5\end{array}$ & 2 & 4 & 20 & 67 & 76 & 32 & 18 & 19 & 13 & 4 & 255 \\
\hline $\begin{array}{l}\text { AIME } \\
\text { Decile } 6\end{array}$ & 0 & 2 & 17 & 39 & 40 & 42 & 30 & 26 & 20 & 27 & 243 \\
\hline $\begin{array}{l}\text { AIME } \\
\text { Decile } 7\end{array}$ & 0 & 0 & 2 & 15 & 39 & 51 & 44 & 36 & 28 & 21 & 236 \\
\hline $\begin{array}{l}\text { AIME } \\
\text { Decile } 8\end{array}$ & 0 & 0 & 0 & 6 & 20 & 50 & 47 & 38 & 36 & 28 & 225 \\
\hline $\begin{array}{l}\text { AIME } \\
\text { Decile } 9\end{array}$ & 0 & 0 & 0 & 3 & 10 & 20 & 41 & 37 & 56 & 48 & 215 \\
\hline $\begin{array}{l}\text { AIME } \\
\text { Decile } \\
10\end{array}$ & 0 & 0 & 0 & 0 & 3 & 10 & 19 & 48 & 60 & 66 & 206 \\
\hline Total & 282 & 258 & 250 & 254 & 260 & 238 & 231 & 231 & 231 & 204 & 2439 \\
\hline
\end{tabular}

The sum of diagonal elements $=797$. The correlation factor $=0.795$. 
Appendix Table 2: The Distribution of Wealth Deciles by Pension Wealth Deciles for Early Boomer HRS Households

\begin{tabular}{|c|c|c|c|c|c|c|c|c|c|c|c|}
\hline Deciles & $\begin{array}{c}\text { Wealth } \\
\text { Decile } 1\end{array}$ & $\begin{array}{l}\text { Wealth } \\
\text { Decile } 2\end{array}$ & $\begin{array}{l}\text { Wealth } \\
\text { Decile } 3\end{array}$ & $\begin{array}{l}\text { Wealth } \\
\text { Decile } 4\end{array}$ & $\begin{array}{l}\text { Wealth } \\
\text { Decile } 5\end{array}$ & $\begin{array}{l}\text { Wealth } \\
\text { Decile } 6\end{array}$ & $\begin{array}{l}\text { Wealth } \\
\text { Decile } 7\end{array}$ & $\begin{array}{l}\text { Wealth } \\
\text { Decile } 8\end{array}$ & $\begin{array}{l}\text { Wealth } \\
\text { Decile } 9\end{array}$ & $\begin{array}{l}\text { Wealth } \\
\text { Decile } \\
10 \\
\end{array}$ & Total \\
\hline $\begin{array}{l}\text { Pension } \\
\text { Deciles } \\
1 \text { - } 3\end{array}$ & 250 & 184 & 120 & 90 & 60 & 37 & 23 & 18 & 15 & 22 & 819 \\
\hline $\begin{array}{l}\text { Pension } \\
\text { Decile } 4\end{array}$ & 24 & 35 & 34 & 44 & 29 & 19 & 10 & 13 & 4 & 7 & 219 \\
\hline $\begin{array}{l}\text { Pension } \\
\text { Decile } 5\end{array}$ & 7 & 25 & 55 & 39 & 37 & 26 & 21 & 15 & 9 & 8 & 242 \\
\hline $\begin{array}{l}\text { Pension } \\
\text { Decile } 6 \\
\end{array}$ & 1 & 11 & 25 & 33 & 46 & 49 & 34 & 18 & 15 & 9 & 241 \\
\hline $\begin{array}{l}\text { Pension } \\
\text { Decile } 7 \\
\end{array}$ & 0 & 3 & 12 & 30 & 42 & 40 & 43 & 26 & 19 & 16 & 231 \\
\hline $\begin{array}{l}\text { Pension } \\
\text { Decile } 8 \\
\end{array}$ & 0 & 0 & 4 & 14 & 36 & 38 & 49 & 54 & 25 & 17 & 237 \\
\hline $\begin{array}{l}\text { Pension } \\
\text { Decile } 9 \\
\end{array}$ & 0 & 0 & 0 & 4 & 10 & 27 & 40 & 63 & 66 & 28 & 238 \\
\hline $\begin{array}{l}\text { Pension } \\
\text { Decile } \\
10 \\
\end{array}$ & 0 & 0 & 0 & 0 & 0 & 2 & 11 & 24 & 78 & 97 & 212 \\
\hline Total & 282 & 258 & 250 & 254 & 260 & 238 & 231 & 231 & 231 & 204 & 2439 \\
\hline
\end{tabular}

The sum of diagonal elements $=640$. The correlation factor $=0.701$. 
Appendix Table 3: The Distribution of Pension Wealth Deciles by AIME Deciles for Early Boomer HRS Households

\begin{tabular}{|c|c|c|c|c|c|c|c|c|c|c|c|}
\hline Deciles & $\begin{array}{c}\text { AIME } \\
\text { Decile } 1\end{array}$ & $\begin{array}{c}\text { AIME } \\
\text { Decile } 2\end{array}$ & $\begin{array}{c}\text { AIME } \\
\text { Decile } 3\end{array}$ & $\begin{array}{c}\text { AIME } \\
\text { Decile } 4\end{array}$ & $\begin{array}{c}\text { AIME } \\
\text { Decile } 5\end{array}$ & $\begin{array}{c}\text { AIME } \\
\text { Decile } 6\end{array}$ & $\begin{array}{c}\text { AIME } \\
\text { Decile } 7\end{array}$ & $\begin{array}{c}\text { AIME } \\
\text { Decile } 8\end{array}$ & $\begin{array}{c}\text { AIME } \\
\text { Decile } 9\end{array}$ & $\begin{array}{c}\text { AIME } \\
\text { Decile } \\
10 \\
\end{array}$ & Total \\
\hline $\begin{array}{c}\text { Pension } \\
\text { Deciles } \\
1-3\end{array}$ & 234 & 191 & 131 & 89 & 59 & 45 & 29 & 22 & 14 & 5 & 819 \\
\hline $\begin{array}{l}\text { Pension } \\
\text { Decile } 4\end{array}$ & 21 & 23 & 37 & 35 & 35 & 29 & 16 & 12 & 6 & 5 & 219 \\
\hline $\begin{array}{l}\text { Pension } \\
\text { Decile } 5\end{array}$ & 9 & 17 & 42 & 40 & 40 & 30 & 22 & 24 & 10 & 8 & 242 \\
\hline $\begin{array}{l}\text { Pension } \\
\text { Decile } 6\end{array}$ & 5 & 8 & 16 & 29 & 35 & 37 & 39 & 35 & 29 & 8 & 241 \\
\hline $\begin{array}{l}\text { Pension } \\
\text { Decile } 7\end{array}$ & 5 & 9 & 16 & 12 & 30 & 26 & 34 & 37 & 32 & 30 & 231 \\
\hline $\begin{array}{l}\text { Pension } \\
\text { Decile } 8\end{array}$ & 5 & 2 & 9 & 26 & 30 & 25 & 34 & 34 & 37 & 35 & 237 \\
\hline $\begin{array}{l}\text { Pension } \\
\text { Decile } 9\end{array}$ & 7 & 7 & 5 & 8 & 19 & 34 & 32 & 36 & 45 & 45 & 238 \\
\hline $\begin{array}{l}\text { Pension } \\
\text { Decile } \\
10\end{array}$ & 2 & 6 & 4 & 9 & 7 & 17 & 30 & 25 & 42 & 70 & 212 \\
\hline Total & 288 & 263 & 260 & 248 & 255 & 243 & 236 & 225 & 231 & 206 & 2439 \\
\hline
\end{tabular}

The sum of diagonal elements $=529$. The correlation factor $=0.631$. 
Appendix Table 4: The Distribution of Wealth Deciles by W2 Earnings Deciles for Selected Early Boomer HRS Households

\begin{tabular}{|c|c|c|c|c|c|c|c|c|c|c|c|}
\hline Deciles & $\begin{array}{c}\text { Wealth } \\
\text { Decile } 1\end{array}$ & $\begin{array}{l}\text { Wealth } \\
\text { Decile } 2\end{array}$ & $\begin{array}{l}\text { Wealth } \\
\text { Decile } 3\end{array}$ & $\begin{array}{l}\text { Wealth } \\
\text { Decile } 4\end{array}$ & $\begin{array}{l}\text { Wealth } \\
\text { Decile } 5\end{array}$ & $\begin{array}{l}\text { Wealth } \\
\text { Decile } 6\end{array}$ & $\begin{array}{l}\text { Wealth } \\
\text { Decile } 7\end{array}$ & $\begin{array}{l}\text { Wealth } \\
\text { Decile } 8\end{array}$ & $\begin{array}{l}\text { Wealth } \\
\text { Decile } 9\end{array}$ & $\begin{array}{l}\text { Wealth } \\
\text { Decile } \\
10 \\
\end{array}$ & Total \\
\hline $\begin{array}{l}\text { W2 } \\
\text { Decile } 1\end{array}$ & 51 & 7 & 3 & 7 & 1 & 0 & 2 & 1 & 1 & 0 & 73 \\
\hline $\begin{array}{l}\text { W2 } \\
\text { Decile } 2\end{array}$ & 20 & 30 & 8 & 6 & 3 & 2 & 0 & 1 & 2 & 0 & 72 \\
\hline $\begin{array}{l}\text { W2 } \\
\text { Decile } 3\end{array}$ & 3 & 19 & 25 & 10 & 5 & 1 & 1 & 0 & 2 & 3 & 69 \\
\hline $\begin{array}{l}\text { W2 } \\
\text { Decile } 4\end{array}$ & 0 & 11 & 15 & 16 & 9 & 5 & 3 & 3 & 1 & 0 & 63 \\
\hline $\begin{array}{l}\text { W2 } \\
\text { Decile } 5\end{array}$ & 0 & 3 & 7 & 17 & 14 & 13 & 8 & 2 & 1 & 0 & 65 \\
\hline $\begin{array}{l}\text { W2 } \\
\text { Decile } 6\end{array}$ & 0 & 1 & 3 & 11 & 17 & 11 & 12 & 7 & 8 & 4 & 74 \\
\hline $\begin{array}{l}\text { W2 } \\
\text { Decile } 7\end{array}$ & 0 & 0 & 3 & 2 & 7 & 20 & 14 & 8 & 4 & 5 & 61 \\
\hline $\begin{array}{l}\text { W2 } \\
\text { Decile } 8\end{array}$ & 0 & 0 & 1 & 1 & 8 & 10 & 15 & 14 & 10 & 6 & 64 \\
\hline $\begin{array}{l}\text { W2 } \\
\text { Decile } 9\end{array}$ & 0 & 0 & 0 & 1 & 1 & 5 & 6 & 21 & 11 & 10 & 55 \\
\hline $\begin{array}{l}\text { W2 } \\
\text { Decile } \\
10\end{array}$ & 0 & 0 & 0 & 0 & 0 & 1 & 4 & 4 & 23 & 27 & 59 \\
\hline Total & 74 & 71 & 62 & 71 & 65 & 68 & 65 & 61 & 63 & 55 & 655 \\
\hline
\end{tabular}

The sum of diagonal elements $=213$. The correlation factor $=0.812$. 
Appendix Table 5: The Distribution of AIME Deciles by W2 Earnings Deciles for Selected Early Boomer HRS Households

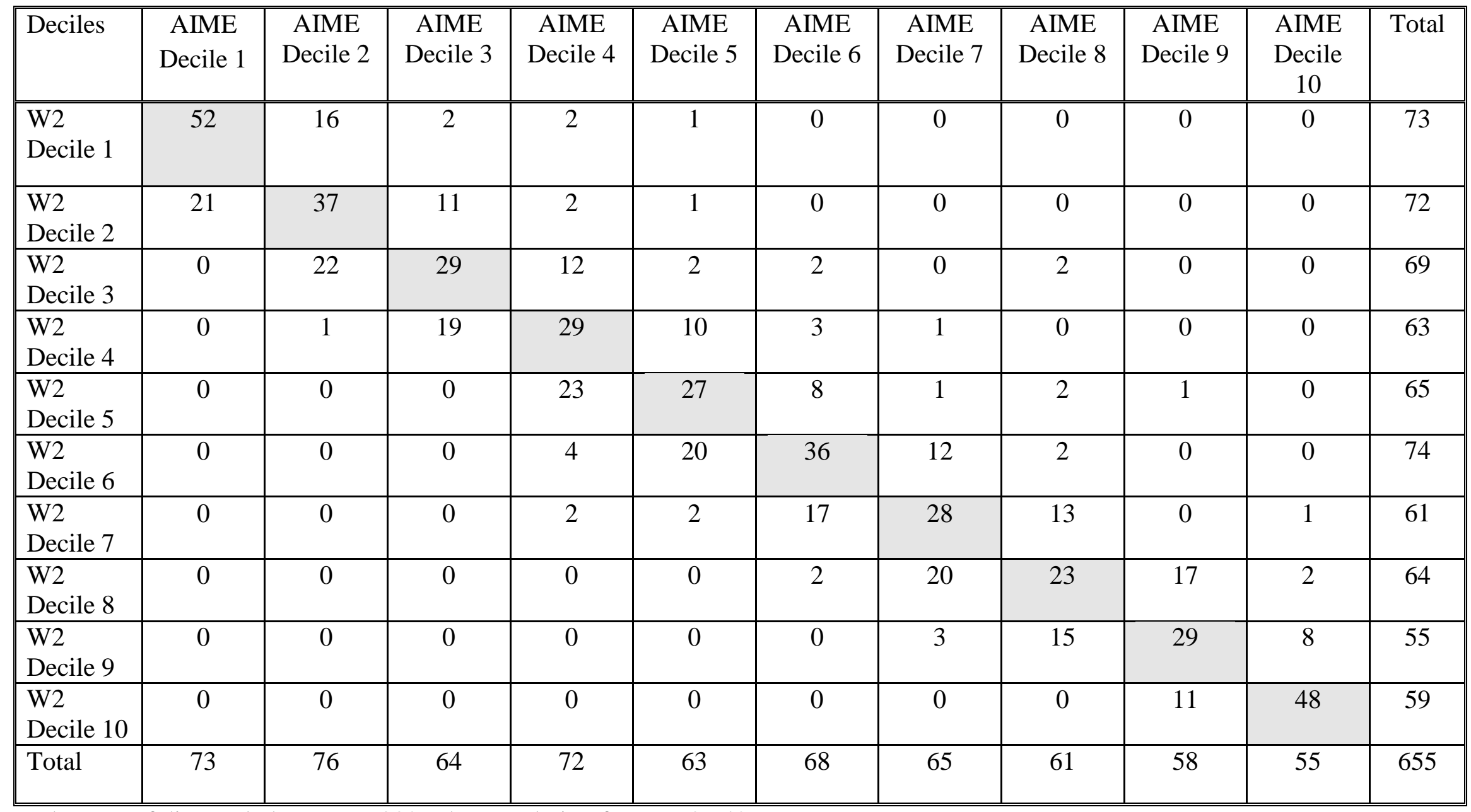

The sum of diagonal elements $=338$. The correlation factor $=0.948$. 
Appendix Table 6: Measures of Distributions of Family Social Security Benefits and Taxes Based on AIME for Alternative Means Tests

\begin{tabular}{|c|c|c|c|c|c|c|c|c|c|c|c|}
\hline & \multicolumn{11}{|c|}{ A. Baseline- Annualized Family AIME deciles: 2004 (2004 dollars) } \\
\hline & $0-10 \mathrm{~K}$ & $10-19$ & $19-30$ & $30-39$ & $39-50$ & $50-62$ & $62-74$ & $74-86$ & $86-103$ & $103+$ & All \\
\hline Average family lifetime taxes & $\$ 26 \mathrm{~K}$ & 77 & 126 & 179 & 228 & 286 & 338 & 402 & 459 & 604 & 272 \\
\hline Average family lifetime benefits & 34 & 111 & 162 & 196 & 262 & 296 & 345 & 388 & 410 & 476 & 268 \\
\hline $\begin{array}{l}\text { \% by which benefits are changed by } \\
\text { redistribution }\end{array}$ & $39 \%$ & 46 & 30 & 11 & 17 & 5 & 4 & -2 & -9 & -20 & - \\
\hline \multirow[t]{2}{*}{$\begin{array}{l}\text { Share of total benefits redistributed to } \\
\text { decile }\end{array}$} & $0.38 \%$ & 1.30 & 1.40 & 0.72 & 1.44 & 0.54 & 0.45 & -0.30 & -1.56 & -4.37 & 6.23 \\
\hline & \multicolumn{11}{|c|}{ B. Annualized Family AIME Deciles with Means Test Based on AIME: 2004 (2004 dollars) } \\
\hline Average family lifetime benefits & 36 & 111 & 162 & 196 & 262 & 296 & 345 & 320 & 335 & 387 & 245 \\
\hline $\begin{array}{l}\text { \% by which benefits are changed by } \\
\text { redistribution \& paying off deficit }\end{array}$ & $39 \%$ & 46 & 30 & 11 & 17 & 5 & 4 & -19 & -26 & -35 & - \\
\hline $\begin{array}{l}\text { Share of total benefits redistributed to } \\
\text { decile \& paying off deficit }\end{array}$ & $0.38 \%$ & 1.30 & 1.40 & 0.72 & 1.44 & 0.54 & 0.45 & -2.79 & -4.37 & -7.68 & -14.84 \\
\hline & \multicolumn{11}{|c|}{ C. Annualized Family AIME Deciles with Means Test Based on Total Wealth: 2004 (2004 dollars) } \\
\hline Average family lifetime benefits & 36 & 109 & 159 & 190 & 255 & 277 & 323 & 361 & 367 & 406 & 248 \\
\hline $\begin{array}{l}\text { \% by which benefits are changed by } \\
\text { redistribution \& paying off deficit }\end{array}$ & $39 \%$ & 44 & 28 & 8 & 14 & -1 & -3 & -9 & -19 & -32 & - \\
\hline $\begin{array}{l}\text { Share of total benefits redistributed to } \\
\text { decile \& paying off deficit }\end{array}$ & $0.38 \%$ & 1.23 & 1.30 & 0.52 & 1.17 & -0.15 & -0.36 & -1.27 & -3.18 & -6.97 & -11.93 \\
\hline & \multicolumn{11}{|c|}{ D. Annualized Family AIME Deciles with Means Test Based on Pension Wealth: 2004 (2004 dollars) } \\
\hline Average family lifetime benefits & 36 & 109 & 159 & 188 & 252 & 275 & 321 & 361 & 372 & 414 & 249 \\
\hline $\begin{array}{l}\text { \% by which benefits are changed by } \\
\text { redistribution \& paying off deficit }\end{array}$ & $39 \%$ & 43 & 28 & 7 & 13 & -2 & -3 & -9 & -18 & -30 & - \\
\hline $\begin{array}{l}\text { Share of total benefits redistributed to } \\
\text { decile \& paying off deficit }\end{array}$ & $0.37 \%$ & 1.22 & 1.31 & 0.43 & 1.06 & -0.23 & -0.42 & -1.30 & -2.98 & -6.70 & -11.63 \\
\hline
\end{tabular}

*Age eligible families in 2004 include all families with at least one member being 51 to 56 years of age in 2004. Households with at least one member identified as a non-covered employee are excluded. Households with top and bottom $1 \%$ of wealth are excluded.

** We define the amount of benefits redistributed to members of each decile as the difference between (1) the benefits currently paid to members of the indicated decile, and (2) the benefits that would be paid to members of that decile if their benefits represented the same proportion of the taxes they paid over their worklife as found for the average individual (or household) in the sample. 
Appendix Table 7: Measures of Distributions of Family Social Security Benefits and Taxes Based on Total Wealth for Alternative Means Tests

\begin{tabular}{|c|c|c|c|c|c|c|c|c|c|c|c|}
\hline & \multicolumn{11}{|c|}{ A. Base line- Family Wealth deciles: 2004 (2004 dollars) } \\
\hline & $0-95 \mathrm{~K}$ & $95-171$ & $171-252$ & $252-355$ & $355-493$ & $493-630$ & $630-796$ & $\begin{array}{l}796- \\
1078\end{array}$ & $\begin{array}{l}1078- \\
1510\end{array}$ & $1510^{+}$ & All \\
\hline Average family lifetime taxes & $\$ 36 \mathrm{~K}$ & 99 & 145 & 208 & 256 & 325 & 352 & 394 & 437 & 474 & 272 \\
\hline Average family lifetime benefits & 40 & 118 & 170 & 224 & 273 & 323 & 347 & 383 & 389 & 414 & 268 \\
\hline $\begin{array}{l}\text { \% by which benefits are changed by } \\
\text { redistribution }\end{array}$ & $13 \%$ & 21 & 20 & 9 & 9 & 1 & 0 & -1 & -10 & -11 & - \\
\hline \multirow[t]{2}{*}{$\begin{array}{l}\text { Share of total benefits redistributed to } \\
\text { decile }\end{array}$} & $0.17 \%$ & 0.78 & 1.04 & 0.71 & 0.80 & 0.12 & 0.03 & -0.17 & -1.52 & -1.97 & 3.66 \\
\hline & \multicolumn{11}{|c|}{ B. Family Wealth Deciles with Means Test Based on AIME: 2004 (2004 dollars) } \\
\hline Average family lifetime benefits & 40 & 118 & 170 & 218 & 261 & 294 & 308 & 340 & 338 & 360 & 245 \\
\hline $\begin{array}{l}\text { \% by which benefits are changed by } \\
\text { redistribution \& paying off deficit }\end{array}$ & $13 \%$ & 21 & 20 & 9 & 6 & -4 & -8 & -12 & -21 & -22 & - \\
\hline \multirow[t]{2}{*}{$\begin{array}{l}\text { Share of total benefits redistributed to } \\
\text { decile \& paying off deficit }\end{array}$} & $0.16 \%$ & 0.78 & 1.04 & 0.64 & 0.37 & -0.97 & -1.41 & -1.77 & -3.41 & -3.96 & -11.52 \\
\hline & \multicolumn{11}{|c|}{ C. Family Wealth Deciles with Means Test Based on Total Wealth: 2004 (2004 dollars) } \\
\hline Average family lifetime benefits & 40 & 118 & 170 & 224 & 273 & 323 & 347 & 327 & 327 & 342 & 248 \\
\hline $\begin{array}{l}\text { \% by which benefits are changed by } \\
\text { redistribution \& paying off deficit }\end{array}$ & $13 \%$ & 21 & 20 & 9 & 9 & 1 & 0.2 & -16 & -26 & -27 & - \\
\hline \multirow[t]{3}{*}{$\begin{array}{l}\text { Share of total benefits redistributed to } \\
\text { decile \& paying off deficit }\end{array}$} & $0.17 \%$ & 0.78 & 1.04 & 0.71 & 0.80 & 0.12 & 0.03 & -2.25 & -4.12 & -4.64 & -11.01 \\
\hline & \multicolumn{11}{|c|}{ D. Family Wealth Deciles with Means Test Based on Pension Wealth: 2004 (2004 dollars) } \\
\hline & $0-95 \mathrm{~K}$ & $95-171$ & $171-252$ & 252-355 & $355-493$ & $493-630$ & $630-796$ & $\begin{array}{l}796- \\
1078 \\
\end{array}$ & $\begin{array}{l}1078- \\
1510\end{array}$ & $1510^{+}$ & All \\
\hline Average family lifetime benefits & 40 & 118 & 170 & 222 & 268 & 306 & 317 & 342 & 339 & 363 & 249 \\
\hline $\begin{array}{l}\text { \% by which benefits are changed by } \\
\text { redistribution } \& \text { paying off deficit }\end{array}$ & $13 \%$ & 21 & 20 & 9 & 6 & -4 & -8 & -12 & -21 & -22 & - \\
\hline $\begin{array}{l}\text { Share of total benefits redistributed to } \\
\text { decile \& paying off deficit }\end{array}$ & $0.16 \%$ & 0.78 & 1.04 & 0.66 & 0.60 & -0.53 & -1.07 & -1.71 & -3.35 & -3.83 & -10.49 \\
\hline
\end{tabular}

*Age eligible families in 2004 include all families with at least one member being 51 to 56 years of age in 2004. Households with at least one member being identified as a non-covered employee are excluded. Households with top and bottom $1 \%$ of wealth are excluded.

** We define the amount of benefits redistributed to members of each decile as the difference between (1) the benefits currently paid to members of the indicated decile, and (2) the benefits that would be paid to members of that decile if their benefits represented the same proportion of the taxes they paid over their worklife as found for the average individual (or household) in the sample. 


\section{Alternative Means Tests}

\begin{tabular}{|c|c|c|c|c|c|c|c|c|c|c|c|}
\hline & \multicolumn{11}{|c|}{ A. Base line- Family Pension Wealth deciles: 2004 (2004 dollars) } \\
\hline & 0 & 0 & 0 & $0-12$ & $12-38$ & $38-80$ & $80-145$ & $145-250$ & $250-450$ & $450+$ & All \\
\hline Average family lifetime taxes & 0 & 0 & 139 & 206 & 242 & 311 & 354 & 350 & 391 & 464 & 272 \\
\hline Average family lifetime benefits & & 0 & 166 & 233 & 257 & 312 & 331 & 326 & 349 & 383 & 268 \\
\hline $\begin{array}{l}\text { \% by which benefits are changed by } \\
\text { redistribution }\end{array}$ & & 0 & 21 & 15 & 8 & 2 & -5 & -5 & -9 & -16 & - \\
\hline $\begin{array}{l}\text { Share of total benefits redistributed to } \\
\text { decile }\end{array}$ & & 0 & 3.39 & 0.98 & 0.74 & 0.25 & -0.64 & -0.69 & -1.30 & -2.73 & 5.36 \\
\hline \multicolumn{12}{|c|}{ mily Pension Wealth Deciles with Means } \\
\hline Average family lifetime benefits & & $\overline{0}$ & 162 & 225 & 244 & 288 & 292 & 291 & 304 & 328 & 245 \\
\hline $\begin{array}{l}\text { \% by which benefits are changed by } \\
\text { redistribution \& paying off deficit }\end{array}$ & & 0 & 18 & 11 & 3 & -6 & -16 & -15 & -21 & -28 & - \\
\hline $\begin{array}{l}\text { Share of total benefits redistributed to } \\
\text { decile \& paying off deficit }\end{array}$ & & 0 & 2.91 & 0.72 & 0.26 & -0.65 & -2.10 & -1.99 & -3.00 & -4.77 & -12.51 \\
\hline \multicolumn{12}{|c|}{ C. Family Pension Wealth Deciles with Means Test Based on Total Wealth: 2004 (2004 dollars) } \\
\hline Average family lifetime benefits & & 0 & 161 & 225 & 250 & 300 & 314 & 301 & 304 & 313 & 248 \\
\hline $\begin{array}{l}\text { \% by which benefits are changed by } \\
\text { redistribution \& paying off deficit }\end{array}$ & & 0 & 18 & 11 & 5 & -2 & -10 & -13 & -21 & -31 & - \\
\hline $\begin{array}{l}\text { Share of total benefits redistributed to } \\
\text { decile \& paying off deficit }\end{array}$ & & 0 & 2.86 & 0.71 & 0.45 & -0.19 & -1.28 & -1.62 & -2.99 & -5.30 & -11.38 \\
\hline & \multicolumn{11}{|c|}{ D. Family Pension Wealth Deciles with Means Test Based on Pension Wealth: 2004 (2004 dollars) } \\
\hline Average family lifetime benefits & & 0 & 166 & 233 & 257 & 312 & 331 & 279 & 276 & 309 & 249 \\
\hline $\begin{array}{l}\text { \% by which benefits are changed by } \\
\text { redistribution \& paying off deficit }\end{array}$ & & 0 & 21 & 15 & 8 & 2 & -5 & -19 & -28 & -32 & - \\
\hline $\begin{array}{l}\text { Share of total benefits redistributed to } \\
\text { decile \& paying off deficit }\end{array}$ & & 0 & 3.39 & 0.98 & 0.74 & 0.25 & -0.64 & -2.44 & -4.03 & -5.48 & -12.59 \\
\hline
\end{tabular}

*Age eligible families in 2004 include all families with at least one member being 51 to 56 years of age in 2004. Households with at least one member being identified as a non-covered employee are excluded. Households with top and bottom $1 \%$ of wealth are excluded.

** We define the amount of benefits redistributed to members of each decile as the difference between (1) the benefits currently paid to members of the indicated decile, and (2) the benefits that would be paid to members of that decile if their benefits represented the same proportion of the taxes they paid over their worklife as found for the average individual (or household) in the sample. 
Appendix Table 9: Measures of Distributions of Household Social Security Benefits and Taxes for All Age Eligible*

Households When Ranked by W2 Deciles: Adjusted by Top Quarter of W2 Earnings;

\begin{tabular}{|c|c|c|c|c|c|c|c|c|c|c|c|}
\hline & \multicolumn{11}{|c|}{ A. Base line- W2 Earnings deciles: 2004 (2004 dollars) } \\
\hline & $0-28 \mathrm{~K}$ & $28-123$ & $123-239$ & $239-311$ & $311-407$ & $407-543$ & $543-671$ & 671-841 & $\begin{array}{l}841- \\
1,039\end{array}$ & $1,039+$ & All \\
\hline Average family lifetime taxes & $33 \mathrm{k}$ & 64 & 118 & 150 & 189 & 234 & 307 & 354 & 413 & 571 & 243 \\
\hline Average family lifetime benefits & 36 & 85 & 139 & 163 & 189 & 240 & 296 & 311 & 346 & 448 & 225 \\
\hline $\begin{array}{l}\text { \% by which benefits are changed by } \\
\text { redistribution }\end{array}$ & 15 & 43 & 27 & 17 & 8 & 11 & 4 & -5 & -10 & -15 & - \\
\hline \multirow[t]{2}{*}{$\begin{array}{l}\text { Share of total benefits redistributed to } \\
\text { decile }\end{array}$} & 0.21 & 1.14 & 1.32 & 1.04 & 0.63 & 1.04 & 0.52 & -0.75 & -1.65 & -3.50 & 5.90 \\
\hline & \multicolumn{11}{|c|}{ B. W2 Earnings Adjusted by Top W2 Earnings: 2004 (2004 dollars) } \\
\hline Average family lifetime benefits & 36 & 85 & 139 & 163 & 189 & 240 & 296 & 255 & 279 & 376 & 206 \\
\hline $\begin{array}{l}\text { \% by which benefits are changed by } \\
\text { redistribution \& paying off deficit }\end{array}$ & 15 & 43 & 27 & 17 & 8 & 11 & 4 & -22 & -27 & -29 & - \\
\hline $\begin{array}{l}\text { Share of total benefits redistributed to } \\
\text { decile \& paying off deficit }\end{array}$ & 0.21 & 1.14 & 1.32 & 1.04 & 0.63 & 1.04 & 0.52 & -3.21 & -4.64 & -6.66 & -14.51 \\
\hline
\end{tabular}

*Age eligible families in 2004 include all families with at least one member being 51 to 56 years of age in 2004. Households with at least one member being identified as a non-covered employee are excluded. Households with top and bottom $1 \%$ of wealth are excluded.

** We define the amount of benefits redistributed to members of each decile as the difference between (1) the benefits currently paid to members of the indicated decile, and (2) the benefits that would be paid to members of that decile if their benefits represented the same proportion of the taxes they paid over their worklife as found for the average individual (or household) in the sample. 